\title{
Variability and Trends of Temperature and Rainfall Over Three Agro-Ecological Zones in North Shewa, Central Ethiopia
}

Ashenafi Hailu Shekuru ( $\nabla$ shekuruashenafi@gmail.com )

Ambo University https://orcid.org/0000-0002-1995-8986

Arega Bazezew Berlie

Bahir Dar University

Yechale Kebede Bizuneh

Arba Minch University

\section{Research}

Keywords: Mann-Kendall, Sen's Slope, PCl, SRA, Drought, Ethiopia

Posted Date: August 7th, 2020

DOI: https://doi.org/10.21203/rs.3.rs-53268/v1

License: (c) (i) This work is licensed under a Creative Commons Attribution 4.0 International License.

Read Full License 


\title{
Variability and Trends of Temperature and Rainfall Over Three Agro- Ecological Zones in North Shewa, Central Ethiopia
}

\author{
Ashenafi Hailu Shekuru ${ }^{1}$, Arega Bazezew Berlie ${ }^{2}$ and Yechale Kebede Bizuneh ${ }^{3}$ \\ ${ }^{1} \mathrm{PhD}$ Candidate at Arba Minch University, Ethiopia (Correspondent, shekuruashenafi@gmail.com) \\ ${ }^{2}$ Associate Professor in Geography and Environmental Studies, Bahir Dare University, Ethiopia \\ ${ }^{3}$ Associate Professor in Environmental Sciences, Arba Minch University, Ethiopia
}

\section{Abstract}

This study aims to analyze variability and trends of temperature and rainfall over three agro-ecological zones (AEZs) in Central Ethiopia. Gridded rainfall and temperature data, recorded on daily basis for 35 years (1979 - 2013) at 30 meteorological stations, were used for analysis. While Mann-Kendall test was applied to analyze the trends in rainfall and temperature, Sen's slope estimator was used to determine the magnitude of change. The study detected an upward trend of $0.07^{\circ} \mathrm{Clannum}(p<0.001)$ in mean annual maximum temperature at Kolla AEZ. It also showed an upward trend of 0.06/year $(p<0.001)$ for both Dega and Woina Dega AEZs. Mean annual minimum temperature exhibited an upward trend of $0.03^{\circ} \mathrm{C}$ year at Kolla $(p<0.001)$, Woina Dega $(p<0.05)$, and Dega $(p<0.01)$, signifying a $1.05^{\circ} \mathrm{C}$ increase between 1979 and 2013. Results from precipitation concentration index (PCI) revealed highest percentage (97.1\%) of irregular distributions in annual rainfall pattern at Kolla AEZ, followed by Woina Dega (82.9\%). Standardized rainfall anomalies (SRA) computed in the study also showed higher percentage (28.6\%) of drought in Kolla AEZ, which experienced drought once in every 3 or 4 years. The study revealed negative annual rainfall anomalies for 18 years in Kolla and 16 years in both Dega and Woina Dega AEZs. The reduced precipitation and rise in temperature could trigger wide-ranging influences on agricultural practices and crop production of smallholder farmers. Policymakers and stakeholders should give priority in designing and introducing pro-poor plus geographically differentiated adaptive strategies.

Key Words: Mann-Kendall, Sen's Slope, PCI, SRA, Drought, Ethiopia

\section{Introduction}

Today's global community is facing several critical issues. Climate change and/or variability are amongst the major issues of our time. They are manifested by the ever-increasing world average temperature, melting of glaciers, rising of sea levels, fluctuations in the amount of rainfall, changing weather patterns and the like. Observational records show that the global mean temperature increased by $0.78^{\circ} \mathrm{C}$ between 1850 and 2012. Based on the projections made, the global average temperature could rise between $1.5^{\circ} \mathrm{C}$ and $2^{\circ} \mathrm{C}$ by the end of the $21^{\text {st }}$ century (Befikadu et al. 2019). It is widely observed in many areas of the world that changes in temperature and rainfall patterns are more likely to become hotter and drier under future climate scenarios (Longobardi and Villani 2010; Gebrehiwot and Veen 2013).

Various studies have investigated trends of climate change and variability in the continent of Africa (Kinyangi et al. 2009; Valli et al. 2013). It is reported that the climate of today's Africa is warmer than it was 100 years ago and during the $20^{\text {th }}$ century the continent has been warming at a rate of about $0.05^{\circ} \mathrm{C} /$ decade, with slightly larger warming from June to November than from December to May (Hulme et al. 2001). The region of East Africa is not an exception to this scenario. A very high temperature and rainfall variations and the associated adverse effects have been reported by scholars in the region (Valli et al. 2013; Easterling et al. 
2007). The impact is primarily associated with higher instability in the inter-annual rainfall primarily affecting rain-fed Agriculture (Befikadu et al. 2019).

Ethiopia is one of the countries in East Africa exhibiting variable climatic conditions. It has diverse AEZs which are characterized by a dazzling variety of microclimates and corresponding weather patterns (Astawsegn 2014). Ethiopia has a tropical monsoon climate characterized by wide topographic induced variations. Mean annual rainfall distribution ranges in the country from more than $2000 \mathrm{~mm}$ over the southwestern highlands to a minimum of below $300 \mathrm{~mm}$ over the southeastern and northwestern lowlands (Abebe and Arega 2019). Rainfall distributions over the country are also strongly inconsistent among different seasons (Kew et al. 2017; Fekadu 2015). Moreover, mean annual temperature varies widely from less than $15^{\circ} \mathrm{C}$ over the highlands and above $25^{\circ} \mathrm{C}$ in the lowlands (Kew et al. 2017; Regassa et al. 2010).

It is reported that over the last 40-50 years, the mean annual temperature of Ethiopia has shown $0.2^{\circ} \mathrm{C}$ to $0.28^{\circ} \mathrm{C}$ rise/decade (McSweeney et al. 2010). A rise in average temperature of about $1.3^{\circ} \mathrm{C}$ has also been observed in the country between 1960 and 2006 (Asaminew and Diriba 2015). The rise in average temperature exhibited spatial and temporal variations over the country. Higher rise in temperature was noted in drier areas in the northeast and southeast part of the country (Abebe and Arega 2019). Notably the variability is higher in July-September. The number of "hot days" and "hot nights" has also shown increment (Asaminew and Diriba 2015). Consequently, the country's minimum temperature has increased with $0.37^{\circ} \mathrm{C}$ to $0.4^{\circ} \mathrm{C} /$ decade (Astawsegn 2014). Ethiopia will experience, according to projections, a $1.7^{\circ} \mathrm{C}-2.1^{\circ} \mathrm{C}$ increase in the mean temperature by 2050 (Befikadu et al.2019).

Previous studies reported mixed findings on trends and variability of rainfall in Ethiopia. Asfaw et al. (2018), Wagesho et al. (2013), Gebrehiwot and Veen (2013), Conway (2000a and 2000b), and Abebe and Arega (2019) concluded that the amount and duration of annual and seasonal rainfall show decreasing trends in the country. Viste et al. (2013) and Meze-Hausken (2004), on the other hand, are not able to document a general decreasing trend of rainfall in Ethiopia. A non-significant trend in annual and seasonal rainfall amounts over the country was also reported by Suryabhagavan (2016) and McSweeney et al. (2008). Others such as Teyso and Anjulo (2016), Bewket and Conway (2007) and Rosell and Holmer (2007) indicated that the annual and seasonal rainfall show great space-time variations. There is a general consensus among most of the researchers that rainfall variability is increasing (and predictability is decreasing) in many parts of the country. This has strong implications for crop production, which becomes clear when assessing the change in areas that receive sufficient rain to support crop production (Kassahun 2011; Astawsegn 2014).

Many studies have been conducted to reveal the extent of climate variability at macro levels. There is, however, paucity of studies at local places and differentiated by AEZs (Befikadu et al. 2019). Easterling et al. (2007), Bewket and Conway (2007), Kebede and Bewket (2009), and Abebe and Arega (2019) clearly showed that trends and spatiotemporal variations in rainfall and temperature remain unknown in several localities of Ethiopia. Studies that scientifically investigate long-term and local scale fluctuations in these climate parameters are seriously lacking in many parts of the country. The previously conducted aggregate analyses do not reflect local conditions, which are extremely divergent and, where the negative upshots of climate variability are most felt. This makes it difficult to understand the extent to which climate parameters vary across periods and localities (Gebrehiwot and Veen 2013). North Shewa 
Administrative Zone (NSAZ) of the Oromia National Regional State (ONRS) represents one of the localities within Ethiopia where trends in climate parameters remain largely unexamined and hence, only scanty of information is available here and there in bits and pieces. This study aims to analyze trends and spatiotemporal variations in rainfall and temperature disaggregating by AEZs in the area and attempts to fill the afore-indicated deficit.

\section{Materials and Methods Description of the Study Area}

North Shewa Administrative Zone is located in the Oromia National Regional State of Ethiopia. Its latitudinal and longitudinal locations extend from $9^{\circ} 08^{\prime} 52^{\prime \prime}-10^{\circ} 35^{\prime} 17^{\prime \prime} \mathrm{N}$ and $37^{\circ} 56^{\prime} 13^{\prime \prime}-$ $39^{\circ} 34^{\prime} 47 " \mathrm{E}$, respectively. NSAZ is characterized by varied topographic settings: plain features, highland and pocket lowland areas. It is dissected by high plateaus and mountains associated with hills, valleys and gorges. The altitude of NSAZ extends from about 1000 m.a.s.l., located in Abay gorge in Wara Jarso district to over 3500 m.a.s.l., located in Degem district (Asaminew and Diriba 2015). The study area's varied topographic features resulted in micro climatic variations in its several localities. Vertisols, Cambisols and Lithosols are major soils within the study area. The traditional agro-ecology of NSAZ ranges from highland (Dega) to lowland (Kolla). Dega occupies over 50\% of the total area of the Zone. The second highest proportion of the area falls within midland (Woina Dega) agro-ecology. Kolla occupies small portion of the study area (Fig. 1).

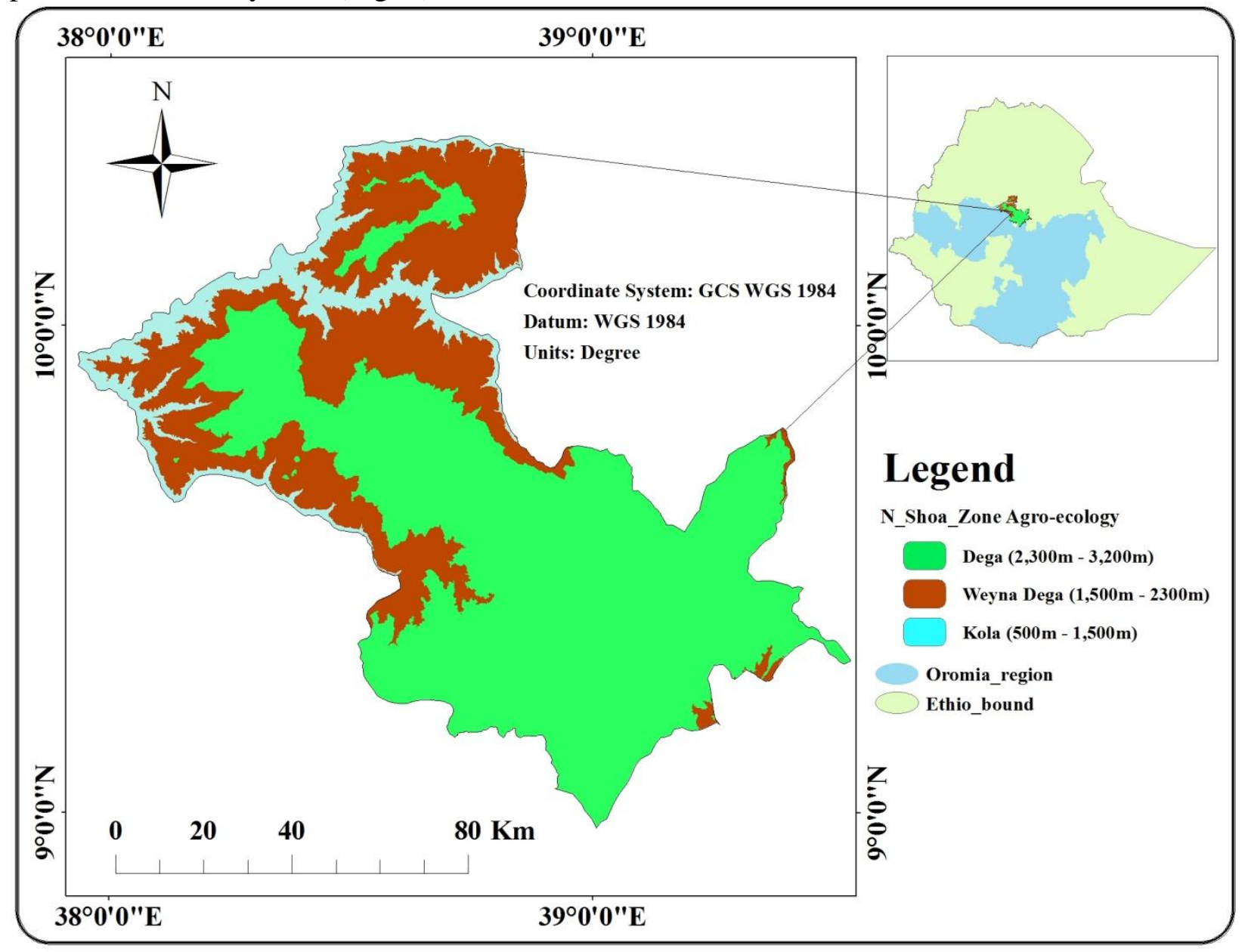


Figure 1. Location of the Study Area

The area understudy receives annual rainfall that ranges from about 532.4 to $1287.8 \mathrm{~mm}$ (Table 3). It gets maximum rain in July and August. The area gets little rain from October to January. There are two distinct rainy seasons in the study area, namely; Kirtemt (summer) and Belg (spring). While the former extends from June to September, the latter extends from February to May. The monthly average temperature of the study area ranges from $15.6^{\circ} \mathrm{C}$ to $19.8^{\circ} \mathrm{C}$ (Table 2 ). The mean monthly minimum temperature ranges from $7.4^{\circ} \mathrm{C}$ to $11.2^{\circ} \mathrm{C}$. The lowest mean monthly temperature is recorded on November. Similarly, the mean monthly maximum temperature of the area ranges from about $20.8^{\circ} \mathrm{C}$ to $28.5^{\circ} \mathrm{C}$. The highest mean monthly temperature is recorded on March. The study area is characterized by mixed farming systems: crop and livestock production.

\section{Research Design and Data Sources}

The study employed a longitudinal research design to detect changes in rainfall and temperature events and to quantify the trends lasting over the study periods (1979-2013). The period of analysis was limited to three and half decades only because of the availability and accessibility of data. This study was conducted by exploiting both primary and secondary sources of data. Global Weather Data for SWAT were obtained from https://globalweather.tamu.edu and used as primary data for the study. It comprises gridded rainfall and temperature data recorded on daily basis for the period between 1979 and 2013 for 30 meteorological stations (Table 1). In this study, gridded data set were preferred over station based data due to high missing values, poor data quality and measurement errors that the latter suffers from.

Table 1. Latitude, Longitude, Altitude and Data Periods of the Meteorological Stations

\begin{tabular}{cccccc}
\hline Agro-ecological Zone & \multicolumn{1}{c}{ Stations } & Longitude & Latitude & Elevation (m) & Period \\
\hline & weatherdata-86381 & 38.125 & 8.586290359 & 2588 & $1979-2013$ \\
& weatherdata-86384 & 38.4375 & 8.586290359 & 2430 & $1979-2013$ \\
& weatherdata-89378 & 37.8125 & 8.89852047 & 2420 & $1979-2013$ \\
& weatherdata-92381 & 38.125 & 9.210749626 & 2821 & $1979-2013$ \\
Dega / Cool to & weatherdata-92384 & 38.4375 & 9.210749626 & 2844 & $1979-2013$ \\
Humid & weatherdata-92388 & 38.75 & 9.210749626 & 2498 & $1979-2013$ \\
$\mathbf{( 2 , 3 0 0 - 3 , 2 0 0 m )}$ & weatherdata-92391 & 39.0625 & 9.210749626 & 2748 & $1979-2013$ \\
& weatherdata-95388 & 38.75 & 9.522979736 & 2627 & $1979-2013$ \\
& weatherdata-95391 & 39.0625 & 9.522979736 & 2640 & $1979-2013$ \\
& weatherdata-98384 & 38.4375 & 9.835209846 & 2400 & $1979-2013$ \\
\hline & weatherdata-86378 & 37.8125 & 8.586290359 & 2062 & $1979-2013$ \\
& weatherdata-86388 & 38.75 & 8.586290359 & 1837 & $1979-2013$ \\
& weatherdata-86391 & 39.0625 & 8.586290359 & 1812 & $1979-2013$ \\
& weatherdata-89381 & 38.125 & 8.89852047 & 2296 & $1979-2013$ \\
& weatherdata-89384 & 38.4375 & 8.89852047 & 2101 & $1979-2013$ \\
& weatherdata-89388 & 38.75 & 8.89852047 & 2138 & $1979-2013$ \\
Woina Dega / Cool & weatherdata-89391 & 39.0625 & 8.89852047 & 2245 & $1979-2013$ \\
Sub Humid & weatherdata-92378 & 37.8125 & 9.210749626 & 1884 & $1979-2013$ \\
$(\mathbf{1 , 5 0 0 - 2 , 3 0 0 m )}$ & weatherdata-95378 & 37.8125 & 9.522979736 & 1731 & $1979-2013$ \\
& weatherdata-95384 & 38.4375 & 9.522979736 & 2067 & $1979-2013$ \\
& weatherdata-98378 & 37.8125 & 9.835209846 & 1602 & $1979-2013$
\end{tabular}




\begin{tabular}{clcccc} 
& weatherdata-98388 & 38.75 & 9.835209846 & 1894 & $1979-2013$ \\
& weatherdata-98391 & 39.0625 & 9.835209846 & 1677 & $1979-2013$ \\
& weatherdata-101378 & 37.8125 & 10.1473999 & 2244 & $1979-2013$ \\
& weatherdata-101381 & 38.125 & 10.1473999 & 2268 & $1979-2013$ \\
& weatherdata-101388 & 38.75 & 10.1473999 & 1713 & $1979-2013$ \\
\hline \multirow{2}{*}{ Kola / Warm Semi } & weatherdata-95381 & 38.1250 & 9.522979736 & 1272 & $1979-2013$ \\
Arid & weatherdata-98381 & 38.1250 & 9.835209846 & 1357 & $1979-2013$ \\
$(\mathbf{5 0 0 - 1 , 5 0 0 m )}$ & weatherdata-101384 & 38.4375 & 10.1473999 & 1295 & $1979-2013$ \\
& weatherdata-101391 & 39.0625 & 10.1473999 & 1372 & $1979-2013$ \\
\hline
\end{tabular}

Source: https://globalweather.tamu.edu

\section{Method of Data Analysis}

Non-Parametric Trend Tests and Change-Point Detection software packages in R (Version 1.1.1) along with Microsoft Excel spreadsheet were used to analyze the primary time series and longterm meteorological data records. The following indices and tests were conducted for analyzing the spatiotemporal variations in rainfall and temperature within the study area at different agroecological levels.

Coefficient of Variation (CV):- is a statistical measure of how the individual data value varies from the mean value. A greater value of $\mathrm{CV}$ is the indicator of larger spatial variability, and vice versa (Chakraborty et al. 2013). It is computed using the following equation:

$$
\mathrm{CV}=\frac{\sigma}{\overline{\mathrm{X}}} * 100
$$

Where, CV is the coefficient of variation, $\sigma$ is the standard deviation (SD) and ${ }^{-} \mathrm{x}$ is the mean. Accordingly, $\mathrm{CV}$ values $<20 \%$ denotes less variable, between $20 \%$ and $30 \%$ denotes moderately variable and $>30 \%$ denotes high variability of rainfall.

Precipitation Concentration Index (PCI):- is a measure of relative distribution. It is a means to represent spatial variability of rainfall patterns. PCI signify rainfall concentration in terms of distribution and variability and is computed on annual and seasonal scale using the following equations, respectively.

$$
\begin{aligned}
\mathrm{PCI}_{\text {Annual }} & =\frac{\sum_{i=1}^{12} \mathrm{pi}^{2}}{\left(\sum_{i=1 p i}^{12}\right)^{2}} \times 100, \\
\mathrm{PCI}_{\text {Seasnal }} & =\frac{\sum_{\mathrm{i}=1}^{4} \mathrm{pi}^{2}}{\left(\sum_{\mathrm{i}=1}^{4} \mathrm{pi}\right) 2} * 33
\end{aligned}
$$

Where, pi is the monthly precipitation in month $\mathrm{i}$

According to scholars' categorization, PCI values of less than 10 signify a uniform precipitation distribution (low precipitation concentration); PCI values between 11 and 15 signify a moderate precipitation concentration; values from 16 to 20 signify irregular distribution and values greater than 20 signify a strong irregularity (high precipitation concentration) of precipitation distribution (De Luis et al. 2011; Valli et al. 2013; Al-Shamarti 2016) 
Mann-Kendall Test: - is a non-parametric statistical test which is widely applied and most effective method to determine whether a time series has a monotonic upward or downward trend (Feng et al. 2016). This test is chosen over other statistical techniques (available to detect trends within time series data) for it does not require that the data be normally distributed or linear. It can test trends in a time series without requiring normality or linearity which is distribution-free test (Wang et al. 2008). It is also less sensitive to outliers or robust against the influence of extremes (Kendall 1975; Mann 1945; Poudel and Shaw 2016). Hence, it is highly recommended for general use by the World Meteorological Organization (Abebe and Arega 2019).

MK test is used to ascertain the existence of a statistically significant or non-significant trend in rainfall and temperature variability (Jain and Kumar 2012). It measures rainfall and temperature variability on both annual time scale (inter-annual variability) and seasonal scale (intra-annual variability, season to season) (Longobardi and Villani 2010). The null hypothesis $\left(H_{o}\right)$ for this test is that there is no trend, and the alternative hypothesis $\left(H_{1}\right)$, is that there is a trend in the twosided test or that there is an upward trend (or downward trend) in the one-sided test. The $Z$ score is computed and the confidence limits of the standard normal $Z$ are equally determined. While positive $(+) Z$ value signifies increasing trends over time, negative $(-) Z$ value indicates decreasing trends (Suryabhagavan 2016).

It is acknowledged in Feng et al. (2016) and Longobardi and Villani (2010), the MK statistic S, the variance statistic $\operatorname{Var}(\sigma)$, and the interrelated standard normal test statistic Z, could be calculated as follows:

$$
S=\sum_{i=1}^{N-1} \sum_{j=i+1}^{N} \operatorname{sgn}(X j-X i),
$$

Where, $N$ is the number of data points; $X_{i}$ and $X_{j}$ are the time series observations. Assuming $\left(X_{j}-X_{i}\right)=\theta$, the value of $\operatorname{sgn}(\theta)$ is computed from:

$$
\operatorname{Sgn}(\theta)=\left\{\begin{array}{c}
+1 \ldots \theta>0 \\
0 \ldots \theta=0 \\
-1 \ldots \theta<0
\end{array} .\right.
$$

Under the hypothesis of independent and randomly distributed random variables, for large samples, when $n \geq 10$ (source), the $\sigma$ statistic is approximately normally distributed, with zero mean and variance:

$$
\sigma^{2}=\frac{n(n-1)(2 n+5)}{18} .
$$

As a consequence, the standardized normal deviate (Z-statistics) distribution will be then calculated as:

$$
\left.\begin{array}{rlrl}
Z & =\frac{S-1}{\sqrt{\operatorname{Var}(S)},} & & \text { if } S>0, \\
& =0, & & \text { if } S=0, \\
& =\frac{S+1}{\sqrt{\operatorname{Var}(S)}}, & & \text { if } S<0 .
\end{array}\right\}
$$


When $\mathrm{Z}$ value exceeds either of the confidence limit lines, it shows a significant trend at a given significance level. Hence, $H_{o}$ is rejected and in place $H_{1}$ is accepted.

Sen's Slope Estimator: - is non-parametric procedure used to quantify trend magnitude in time series data. It is more robust estimator than others due to its relative insensitivity to extreme values (Chattopadhyay and Edwards 2016). Sen's Slope estimator has been widely used for determining the trend magnitude in hydro-meteorological time series (Jain and Kumar 2012). To derive an estimate of the Slope $b_{i}$, the Slopes of all data pairs are computed as:

$$
b_{i}=\frac{X j-X i}{j-i}, i=1,2,3 \ldots, N, j>i,
$$

Where: $x j$ and $x i$ are data values at times $j$ and $i ; j>i$ respectively. The Sen's estimator of the Slope is the median of these $\mathrm{N}$ values of bi:

$$
b=\left\{\begin{array}{l}
b_{\frac{W+1}{2}} \text { if } N \text { is odd } \\
0.5\left[b_{\frac{N}{2}}+b_{\left.\frac{(S+2)}{2}\right]} \text { if } N\right. \text { is even }
\end{array} .\right.
$$

A positive value of $b$ indicates an 'upward trend' (increasing values with time) while a negative value of b indicates a 'downward trend' (Chakraborty et al. 2013).

Standardized Rainfall Anomaly (SRA):- is the difference between the long-term average rainfall (sometimes called a reference value) and the annual rainfall in a given year, and divided by the standard deviation. SRA features have contributed to its acceptance for drought monitoring while enabling to identify the dry and wet years in the record (Svoboda et al. 2012). It is obtained using the following equation (Bewket and Conway 2007).

$$
\mathrm{SRA}=\frac{\mathrm{P}_{t}-\mathrm{P}_{m}}{\sigma},
$$

Where, SRA is standardized rainfall anomaly, $\mathrm{P} t$ is annual rainfall in year $t, \mathrm{P} m$ is long-term mean annual rainfall for the period 1979-2013, and $\sigma$ is the standard deviation of annual rainfall for the period 1979-2013. According to Befikadu et al. (2019), the drought severity is categorized as: extreme drought (SRA $<-1.65)$, severe drought $(1.28>$ SRA $>-1.65)$, moderate drought $(-0.84>$ SRA $>-1.28)$, and no drought $($ SRA $>-0.84)$.

\section{Results and Discussion}

\section{Variability and Trends of Rainfall and Temperature in NSAZ Variability and Trends of Temperature}

Table 2 illustrates the variability and trends of temperature in NSAZ between 1979 and 2013. It shows that the minimum temperature of the area was $9.5^{\circ} \mathrm{C}$ with a maximum of $25.6^{\circ} \mathrm{C}$ and annual average of $17.5^{\circ} \mathrm{C}$. Mann-Kendall test statistics used in the study revealed a statistically significant increasing trend for all long-term average monthly temperature. The overall significant increasing trend that this study revealed for average monthly temperature was found to be more attributed to the increasing trend of mean monthly maximum temperature. The regression coefficient for annual average, maximum and minimum temperature showed an increasing trend at the rate of $0.039^{\circ} \mathrm{C}, 0.056^{\circ} \mathrm{C}$ and $0.022^{\circ} \mathrm{C}$ per annum, respectively (Fig. 2). 
Thus, the rate of increase in the mean annual maximum temperature was faster than the minimum. Studies conducted in other parts of Ethiopia by Teyso and Anjulo (2016), Asfaw et al. (2018), Befikadu et al. (2019) and Abebe and Arega (2019) also found an increase in the longrun mean annual maximum, minimum and average temperature.

Table 2. M-K Test and Sen's Slope on Monthly Minimum, Maximum and Average Temperature (1979-2013)

\begin{tabular}{lrrrrrrrrrrrr}
\hline Month Tmin & Z(M-K) & P-Value & Slope & Tmax & Z(M-K) & P-Value & Slope & Tmean & Z(M-K) & P-Value Slope \\
\hline Jan. & 8.4 & 1.363 & 0.173 & 0.021 & 26.3 & $3.522^{* * *}$ & 0.000 & 0.055 & 17.4 & $3.636^{* * *}$ & 0.000 & 0.040 \\
Feb. & 9.7 & -0.057 & 0.955 & -0.002 & 27.7 & $3.465^{* * *}$ & 0.001 & 0.076 & 18.7 & $2.613^{* *}$ & 0.009 & 0.041 \\
Mar, & 10.8 & 0.937 & 0.349 & 0.016 & 28.5 & $3.124^{* *}$ & 0.002 & 0.056 & 19.7 & $2.982^{* *}$ & 0.003 & 0.039 \\
Apr. & 11.2 & $2.840^{* *}$ & 0.005 & 0.031 & 28.3 & $2.272^{*}$ & 0.023 & 0.040 & 19.8 & $3.153^{* *}$ & 0.002 & 0.040 \\
May & 10.5 & $2.272^{*}$ & 0.023 & 0.020 & 28.1 & $2.926^{* *}$ & 0.003 & 0.065 & 19.3 & $3.522^{* * *}$ & 0.000 & 0.045 \\
June & 11.0 & 1.960 & 0.050 & 0.015 & 26.1 & $3.465^{* * *}$ & 0.001 & 0.073 & 18.5 & $4.033^{* * *}$ & 0.000 & 0.044 \\
July & 11.1 & $3.550^{* * *}$ & 0.000 & 0.024 & 21.2 & $2.272^{*}$ & 0.023 & 0.064 & 16.1 & $2.897 * *$ & 0.004 & 0.045 \\
Aug. & 10.3 & $2.471^{*}$ & 0.013 & 0.023 & 20.8 & $2.556^{*}$ & 0.011 & 0.063 & 15.6 & $3.153^{* *}$ & 0.002 & 0.045 \\
Sept. & 8.5 & $2.670^{* *}$ & 0.008 & 0.024 & 23.6 & $3.068^{* *}$ & 0.002 & 0.063 & 16.0 & $3.266^{* *}$ & 0.001 & 0.045 \\
Oct. & 7.6 & $2.357^{*}$ & 0.018 & 0.034 & 24.7 & $2.045^{*}$ & 0.041 & 0.050 & 16.1 & $2.784^{* *}$ & 0.005 & 0.044 \\
Nov. & 7.4 & $2.613^{* *}$ & 0.009 & 0.038 & 25.7 & 1.562 & 0.118 & 0.027 & 16.6 & $2.613^{* *}$ & 0.009 & 0.026 \\
Dec. & 7.5 & 1.136 & 0.256 & 0.024 & 25.7 & $2.869^{* *}$ & 0.004 & 0.037 & 16.6 & $2.414^{*}$ & 0.016 & 0.027 \\
Ave. & 9.5 & $2.698^{* *}$ & 0.007 & 0.027 & 25.6 & $3.806^{* * *}$ & 0.000 & 0.056 & 17.5 & $3.976^{* * *}$ & 0.000 & 0.037 \\
\hline
\end{tabular}

*. Is statistically significant at $P<0.05 \quad * *$. Is statistically significant at $P<0.01 \quad$ ***. Is statistically significant at $P<0.001$
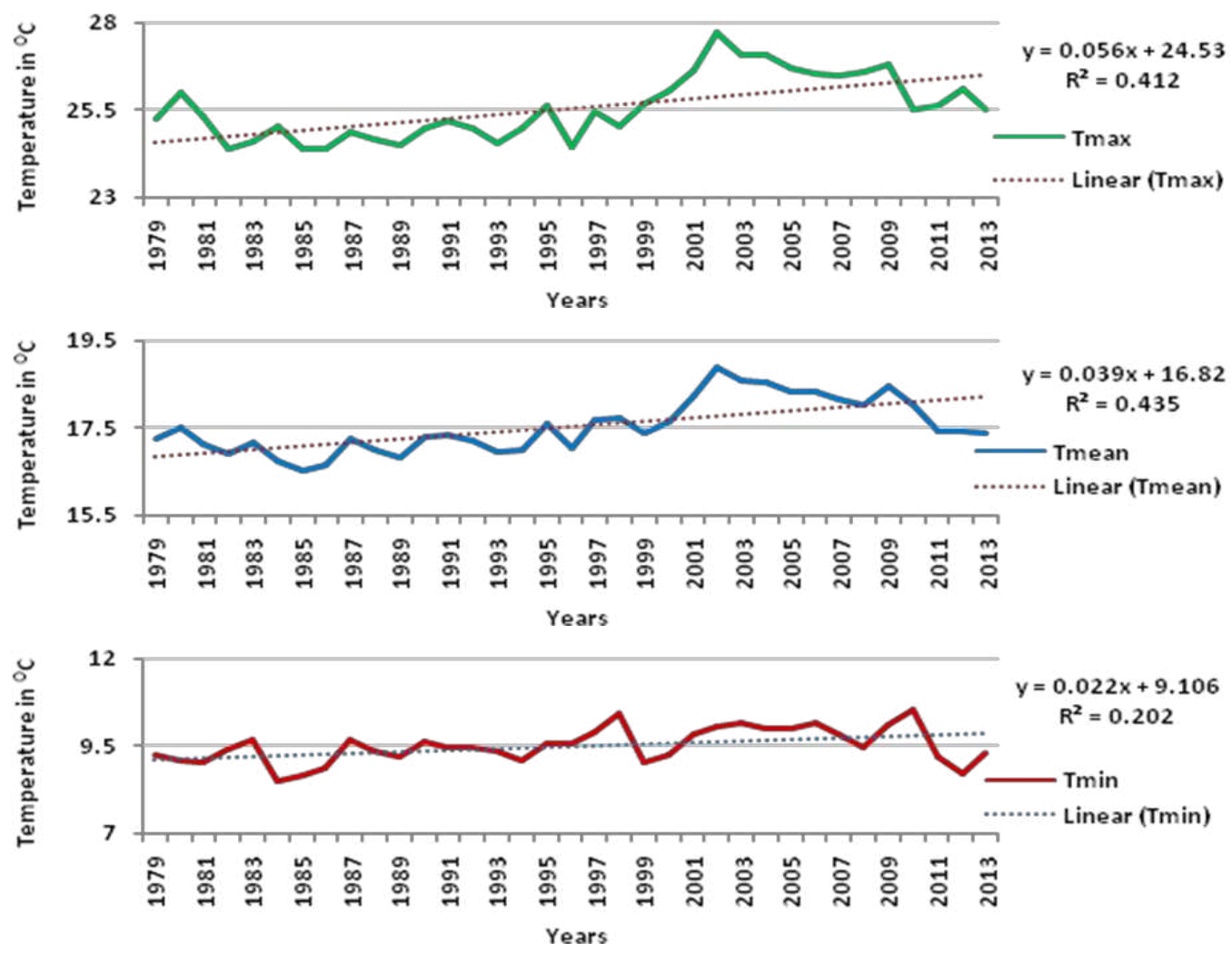

Figure 2. Trends in Long-Term Mean Annual Maximum, Minimum and Average Temperature 
Table 3 shows the monthly, seasonal and annual trends of rainfall within the study area for the years extending from 1979 to 2013. As shown in the table, the long-term mean annual rainfall of the area was $940.2 \mathrm{~mm}$ with a SD of 157.8 and a CV of $16.8 \%$. The highest $(1287.8 \mathrm{~mm})$ and the lowest $(532.4 \mathrm{~mm})$ mean annual rainfall was recorded in 1998 and 2002, respectively. The total annual rainfall of the area heavily concentrated in four months: June, July, August and September (Kiremt season). About $81.6 \%$ of the total rainfall was gained in these months. A considerable amount of rainfall was received during the four months of belg season (i.e February, March, April and May) accounting for about $14.2 \%$ of the annual total rainfall. Thus, kiremt season contributed the highest share of the total annual rainfall of the study area. Similar results were obtained by many other studies conducted in Ethiopia (Asfaw et al. 2018; Ayalew et al. 2012; Suryabhagavan 2016; Gebrehiwot and Veen 2013).

Table 3. Monthly, Seasonal and Annual Rainfall Trend Analysis (1979-2013)

\begin{tabular}{lrrrrrrrrr}
\hline \multicolumn{1}{c}{ Month } & \multicolumn{1}{c}{ Min } & \multicolumn{1}{c}{ Max } & \multicolumn{1}{c}{ Mean } & \multicolumn{1}{c}{ \% } & Std.D & \multicolumn{1}{c}{ CV } & Z(M-K) & P-Value & \multicolumn{1}{l}{ Slope } \\
\hline Jan. & 0.00 & 30.37 & 8.38 & 0.89 & 8.09 & 0.9656 & -0.8521 & 0.3942 & -0.0797 \\
Feb. & 0.01 & 56.29 & 14.50 & 1.54 & 16.46 & 1.1356 & $-2.5563^{* *}$ & 0.01058 & -0.5569 \\
March & 0.16 & 139.41 & 37.03 & 3.94 & 28.55 & 0.7710 & -0.8521 & 0.3942 & -0.3542 \\
April & 3.89 & 99.50 & 42.92 & 4.56 & 27.90 & 0.6500 & 0 & 1 & -0.0067 \\
May & 0.83 & 125.96 & 39.32 & 4.18 & 35.49 & 0.9027 & -0.2556 & 0.7982 & -0.1218 \\
June & 25.05 & 266.33 & 117.35 & 12.48 & 52.08 & 0.4438 & $-2.0734 * *$ & 0.03813 & -1.4552 \\
July & 112.80 & 381.86 & 274.65 & 29.21 & 50.83 & 0.1851 & 1.1361 & 0.2559 & 0.79237 \\
Aug. & 188.78 & 402.78 & 265.01 & 28.19 & 48.14 & 0.1816 & -0.2556 & 0.7982 & -0.1695 \\
Sep. & 37.99 & 174.85 & 109.68 & 11.67 & 33.21 & 0.3027 & -0.5397 & 0.5894 & -0.4428 \\
Oct. & 0.05 & 100.03 & 22.28 & 2.37 & 24.00 & 1.0773 & -0.8521 & 0.3942 & -0.1716 \\
Nov. & 0.06 & 30.27 & 5.20 & 0.55 & 8.14 & 1.5647 & 0.90889 & 0.3634 & 0.02682 \\
Dec. & 0.00 & 15.73 & 3.89 & 0.41 & 4.37 & 1.1243 & -0.1136 & 0.9095 & -0.0022 \\
Belg & 45.71 & 281.24 & 133.77 & 14.23 & 61.56 & 0.4602 & -1.5622 & 0.1183 & -1.7611 \\
Kiremt & 453.01 & 1001.16 & 766.69 & 81.55 & 117.26 & 0.1529 & -0.5681 & 0.57 & -0.9928 \\
Annual & 532.40 & 1287.75 & 940.20 & 100 & 157.78 & 0.1678 & -1.2781 & 0.2012 & -2.8284 \\
\hline
\end{tabular}

**. Is statistically significant at $P<0.05$

Table 3 indicates that the CV of belg season was much higher (46\%) and more variable than kiremt season (15\%). Studies made in other parts of Ethiopia by Rosell and Holmer (2007), Ayalew et al. (2012), Bewket (2009), and Bewket and Conway (2007) documented similar results. Results from Mann-Kendall test revealed a decreasing, but non-significant trend for annual and seasonal (kiremt and belg) rainfall. Statistically significant decreasing trend of rainfall was observed for only two months: February $(\mathrm{p}<.05)$ and June $(\mathrm{p}<.05)$. The regression coefficients for annual, kiremt and belg rainfall showed decreasing trends at the rate of $3.104 \mathrm{~mm}, 1.707 \mathrm{~mm}$ and $1.431 \mathrm{~mm}$ per year, respectively (Fig. 3). Rainfall reduction showed variations between years and amongst kiremt and belg seasons at a rate of $3.104 \mathrm{~mm}, 1.707 \mathrm{~mm}$ and $1.431 \mathrm{~mm}$, respectively. This result of the study negates with the work of Wagesho et al. (2013), Asfaw et al. (2018), and Abebe and Arega (2019) who found significant decreasing trends of annual and kiremt rainfall. The result obtained is, however, similar to the findings of Conway (2000a and 2000b), Viste et al. (2013), McSweeney et al. (2008), Suryabhagavan, (2016), Conway et al. (2004), and Befikadu et al. (2019), who reported statistically nonsignificant trend results.

Table 4 indicates high $(28.6 \%)$ and very high $(71.4 \%)$ annual rainfall concentration (irregular rainfall distribution) in the period between 1979 and 2013. The table, on the other hand, shows 
moderate $(42.9 \%)$ and uniform $(57.1 \%)$ rainfall distribution for Kiremt season during the indicated period. Belg season was mainly (65.7\%) characterized by moderate rainfall distribution. Abebe and Arega (2019), Bewket (2009), Asfaw et al. (2018), Bewket and Conway (2007) and Ayalew et al. (2012) report similar results in which rainfall concentration is higher for kiremt season.
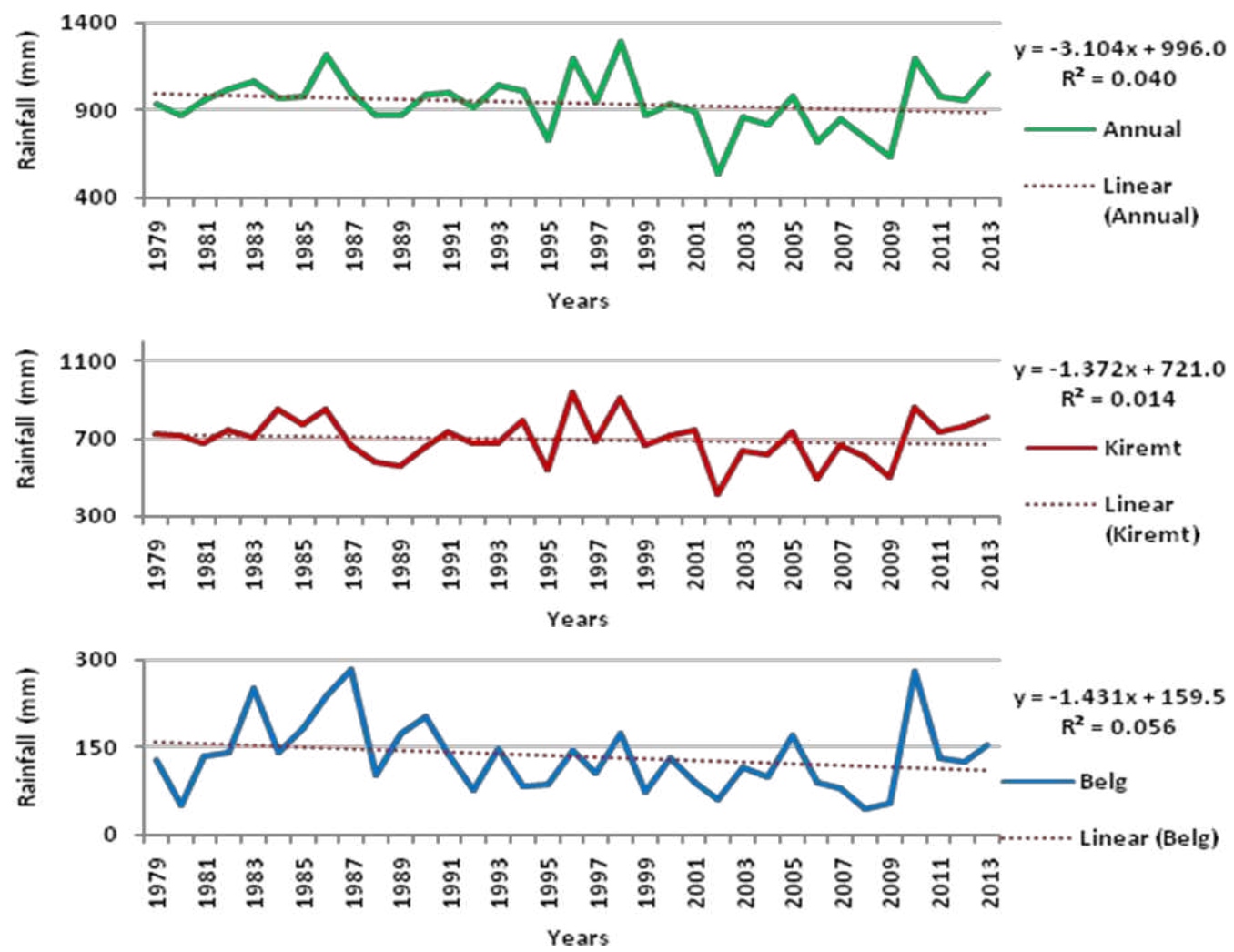

Figure 3. Trends in Mean Annual, Kiremt and Belg Rainfall (1979 - 2013)

Table 4. Annual, Kiremt and Belg Precipitation Concentration Index (PCI) for 1979-2013

\begin{tabular}{llccc}
\hline \multicolumn{1}{c}{ PCI (\%) } & Description & \multicolumn{3}{c}{ Observation Years $(\%)$} \\
\cline { 3 - 4 } & & Annual & Kiremt & Belg \\
\hline$\leq 10$ & Uniform rainfall distribution/low concentration & - & 57.1 & 11.4 \\
$(10-15]$ & Moderate rainfall distribution & - & 42.9 & 65.7 \\
$(15-20]$ & High concentration/irregular rainfall distribution & 28.6 & - & 20 \\
$>20$ & Very high concentration/irregular rainfall distribution & 71.4 & - & 2.8 \\
\hline
\end{tabular}

\section{Variability and Trends in Rainfall and Temperature by AEZs}

Variability and Trends in Temperature by AEZs

Variability and Trends in Mean Annual Maximum Temperature

The annual average maximum temperature for Dega, Woina Dega and Kolla AEZs varies between $22-25^{\circ} \mathrm{C}, 25-29^{\circ} \mathrm{C}$ and $28-31^{\circ} \mathrm{C}$, respectively (Table 5). In this study, approximately equal CV was found for Woina Dega and Kolla AEZs in mean annual maximum temperature over the 35 years (1979-2013) considered. For highland area (Dega AEZ), however, a higher CV 
was found. This suggests existence of variability in mean annual maximum temperature over those years between AEZ. The year 2002 was observed as the hottest year in all AEZs during the period (1979-2013). The coldest year for Dega, Woina Dega and Kolla AEZs was 1982, 1985 and 1986, respectively. The hottest and coldest years are consistent with a study by Mengistu et al. (2014), which reported that AEZs in the Upper Nile basin experienced relatively cold years in the 1980s and warm years from the early 1990s to the 2000s. Results obtained in the present study also go in line with the finding by Befikadu et al. (2019).

Table 5. Annual Maximum Temperature Variability by AEZs (1979 - 2013)

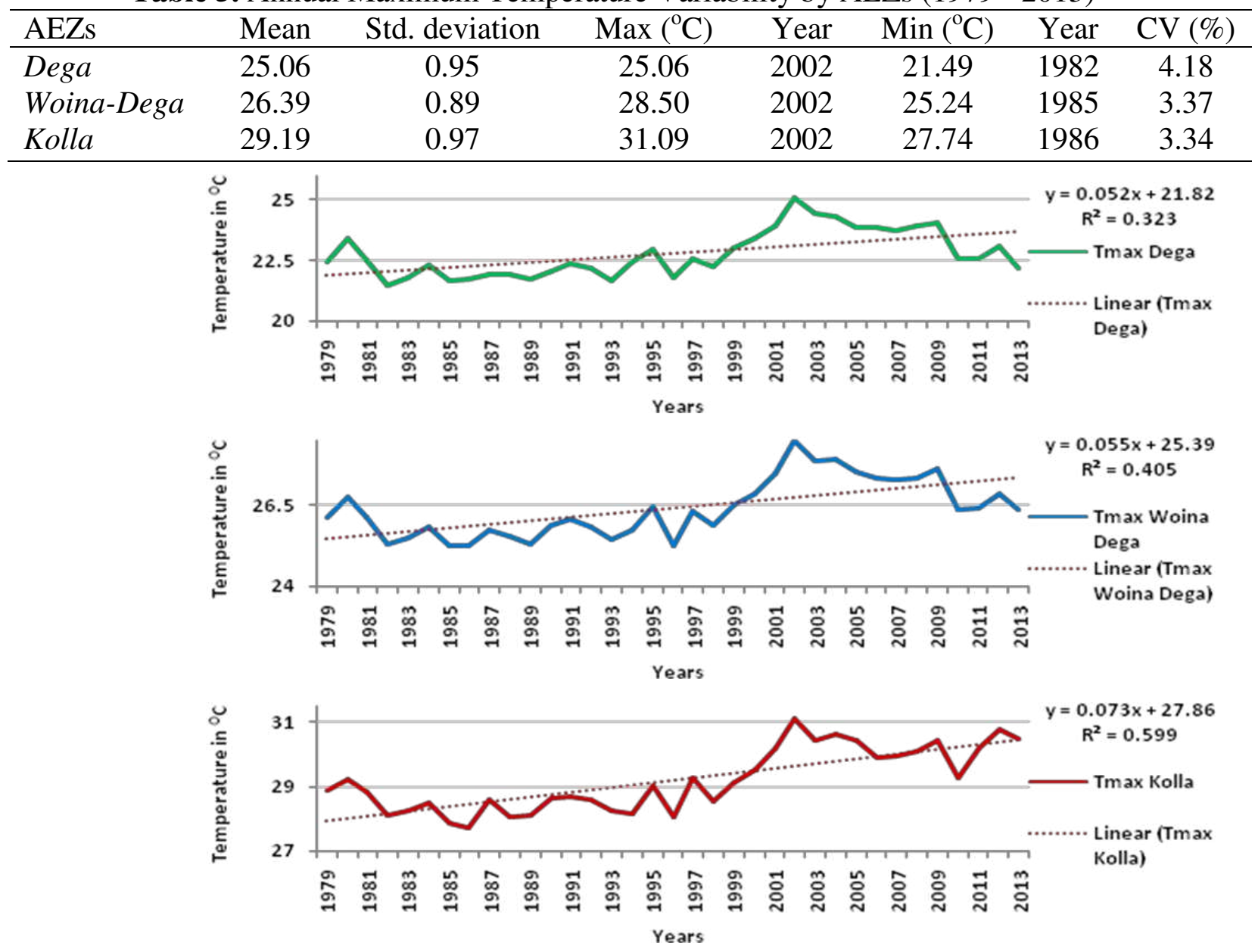

Figure 4. Trends in Mean Annual Maximum Temperatures by AEZs (1979 - 2013)

Fig. 4 and Table 6 show the temporal and spatial variability and trend of mean annual maximum temperature by AEZs. The mean annual maximum temperature showed an increase over the years considered in all AEZs. It exhibited an upward trend of $0.07^{\circ} \mathrm{C} /$ year $(p<0.001)$ for Kolla AEZ, signifying a $0.7^{\circ} \mathrm{C}$ increase per decade between 1979 and 2013. It also showed an upward trend of 0.06/year $(p<0.001)$ for both Dega and Woina Dega AEZs, signifying a $0.6^{\circ} \mathrm{C}$ increase per decade between the afore-indicated years. The warming trend observed in the study area is relatively higher than the historical trend reported at national and sub-national levels. For instance, a warming trend of $0.1^{\circ} \mathrm{C} /$ decade was observed in Ethiopia between 1953 and 1999 (NMA 2007) while it was $0.2^{\circ} \mathrm{C} /$ decade for Addis Ababa from 1951 to 2002 (Conway et 
al.2004). Mengistu et al. (2014) also reported warming of $1.28^{\circ} \mathrm{C}$ and $0.64^{\circ} \mathrm{C}$ over three decades in highland and lowland AEZs implying some possible negative impacts on the lives and livelihoods of smallholder farmers. Despite the difference in the magnitude of increase in the annual average maximum temperature, the general warming trend matches with studies reported both at national level (NMA 2007) and local level (Mengistu et al. 2014).

Table 6. M-K Test and Sen's Slope on Monthly and Annual Maximum Temperature by AEZs

\begin{tabular}{|c|c|c|c|c|c|c|c|c|c|}
\hline \multirow[t]{2}{*}{ Month } & \multicolumn{3}{|l|}{ Dega } & \multicolumn{3}{|l|}{ Woina Dega } & \multicolumn{3}{|l|}{ Kolla } \\
\hline & $\mathrm{Z}(\mathrm{M}-\mathrm{K})$ & P-Value & Slope & $\mathrm{Z}(\mathrm{M}-\mathrm{K})$ & P-Value & Slope & $\mathrm{Z}(\mathrm{M}-\mathrm{K})$ & P-Value & Slope \\
\hline Jan. & $3.1243^{* *}$ & 0.0018 & 0.0588 & $3.4083 * * *$ & 0.0007 & 0.0509 & $4.4877 * * *$ & 0.0000 & 0.0597 \\
\hline Feb. & $3.664 * * *$ & 0.0002 & 0.0967 & $3.1811 * *$ & 0.0015 & 0.0629 & $4.1184 * * *$ & 0.0000 & 0.0673 \\
\hline Mar. & $2.9539 * *$ & 0.0031 & 0.0576 & 3.2379 & 0.0012 & 0.0549 & $3.4083 * * *$ & 0.0007 & 0.0491 \\
\hline Apr. & 1.4769 & 0.1397 & 0.0397 & $2.4142 *$ & 0.0158 & 0.0441 & $3.5504 * * *$ & 0.0004 & 0.0534 \\
\hline May & $2.1018^{*}$ & 0.0356 & 0.0664 & $2.9823 * *$ & 0.0029 & 0.0633 & $4.4308 * * *$ & 0.0000 & 0.0748 \\
\hline June & $3.0107 * *$ & 0.0026 & & $3.3799 * * *$ & 0.0007 & 0.0694 & $4.2604 * * *$ & 0.0000 & 0.0977 \\
\hline July & 1.6758 & 0.0938 & 0.0446 & $2.4142 *$ & 0.0158 & 0.0665 & $2.9255 * *$ & 0.0034 & 0.1029 \\
\hline Aug. & 1.5906 & 0.1117 & 0.0415 & $2.6983^{* *}$ & 0.0070 & 0.0713 & $3.3231 * * *$ & 0.0009 & 0.1084 \\
\hline Sept. & $2.1018 *$ & 0.0356 & 0.0476 & $3.1243^{* *}$ & 0.0018 & 0.0619 & $3.7776 * * *$ & 0.0002 & 0.1129 \\
\hline Oct. & 1.8746 & 0.0609 & 0.0446 & $2.1302^{*}$ & 0.0332 & 0.0508 & $3.0959 * *$ & 0.0020 & 0.0708 \\
\hline Nov. & 1.0225 & 0.3065 & 0.0186 & 1.7042 & 0.0884 & 0.0285 & $2.9255^{* *}$ & 0.0034 & 0.0449 \\
\hline Dec. & $2.7551 * *$ & 0.0059 & 0.0393 & $2.6415^{* *}$ & 0.0083 & 0.0343 & $3.806 * * *$ & 0.0001 & 0.0471 \\
\hline Annual & $3.4936 * * *$ & 0.0005 & 0.0546 & $3.4936 * * *$ & 0.0005 & 0.0546 & $4.4877 * * *$ & 0.0000 & 0.0740 \\
\hline
\end{tabular}

Variability and Trends in Mean Annual Minimum Temperature

The annual average minimum temperature was $8.46^{\circ} \mathrm{C}(\mathrm{CV}=6.12), 9.81^{\circ} \mathrm{C}(\mathrm{CV}=5.18)$ and $10.86^{\circ} \mathrm{C}(\mathrm{CV}=4.49)$ for Dega, Woina Dega and Kolla, respectively (Table 7). It shows relatively high variability in the highland (Dega) area than the other AEZs. The coldest year, during the period ranging from 1979 to 2013, was 1984 in all AEZs. This result goes in line with the finding by Befikadu et al. (2019). It also agrees with the cold and warm years reported among AEZs of the Upper Nile basin (Mengistu et al. 2014). Table 8 and Fig. 5 show an increasing in mean annual minimum temperature in all AEZs over the years stretching from 1979 to 2013. Mean annual minimum temperature exhibited an upward trend of $0.03^{\circ} \mathrm{C} /$ year for Kolla $(p<0.001)$, Woina Dega $(p<0.05)$, and Dega $(p<0.01)$ agro-ecologies, signifying a $1.05^{\circ} \mathrm{C}$ increase between the indicated years. Earlier studies have also shown significant increasing trend for annual average minimum temperature. For instance, Bewket et al. (2014) reported a $0.05^{\circ} \mathrm{C}$ increase per annum in mean annual minimum temperature in lowland and midland AEZs. Conway et al. (2004) also observed an increasing trend of $0.4^{\circ} \mathrm{C} /$ decade in annual average minimum temperature from 1951 to 2002 for Addis Ababa. Besides, a study by Mengistu et al. (2014) found a $0.15^{\circ} \mathrm{C}$ increase per decade in the Upper Nile basin. In addition, mean annual minimum temperature increased by about $0.37^{\circ} \mathrm{C} /$ decade between 1951 and 2006 in a study conducted by McSweeney et al. (2008). Tekleab et al. (2013) also reported significant increases for many stations studied in the Abay basin. This finding shows that the rate with which mean annual maximum temperature increase was far higher than the rate with which mean annual minimum temperature increase in all AEZs over the period considered in the study. This negates 
the result obtained by Befikadu et al. (2019), who reported that the rate of change for mean annual minimum temperature is faster than the mean annual maximum temperature both in time and space.

Table 7. Annual Minimum Temperature Variability by AEZs (1979 - 2013)

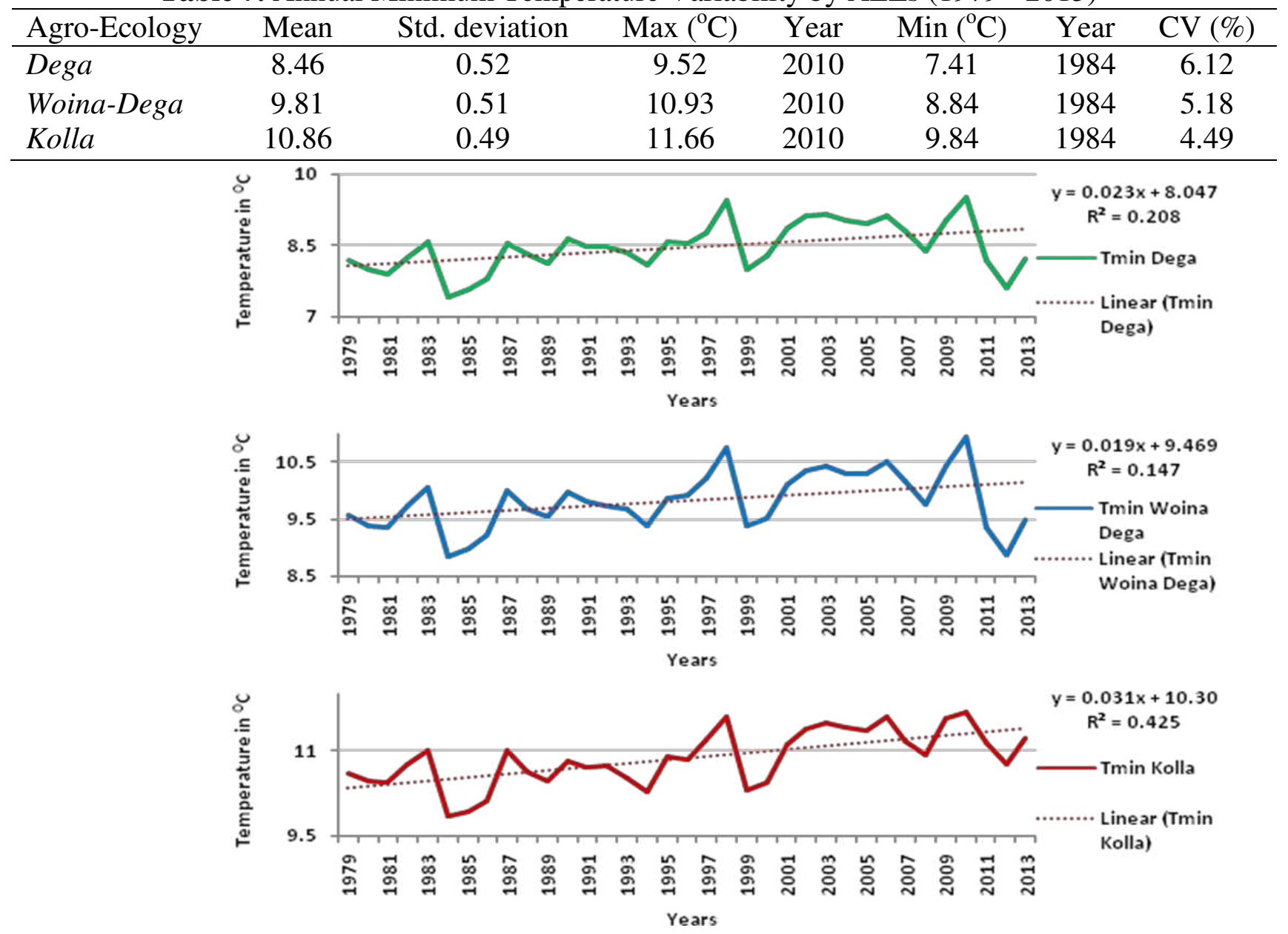

Figure 5. Trends in Mean Annual Minimum Temperatures by AEZs (1979 - 2013)

Table 8. M-K Test and Sen's Slope on Monthly and Annual Minimum Temperature by AEZs

\begin{tabular}{lrrrrrrrrr}
\hline \multirow{2}{*}{ Month } & \multicolumn{1}{l}{ Dega } & \multicolumn{3}{c}{ Woina Dega } & \multicolumn{3}{c}{ Kolla } \\
\cline { 2 - 10 } & Z(M-K) & P-Value & Slope & Z(M-K) & P-Value & Slope & Z(M-K) & P-Value & Slope \\
\hline Jan. & 1.4769 & 0.140 & 0.0272 & 1.1077 & 0.2680 & 0.0158 & $2.329 *$ & 0.0199 & 0.0347 \\
Feb. & 0 & 1.000 & 0.0001 & -0.25563 & 0.7982 & -0.0050 & 0.53965 & 0.5894 & 0.0119 \\
Mar. & 1.3349 & 0.182 & 0.0242 & 0.65327 & 0.5136 & 0.0117 & 1.1645 & 0.2442 & 0.0191 \\
Apr. & $3.0959^{* *}$ & 0.002 & 0.0366 & $2.4995^{*}$ & 0.0124 & 0.0285 & $3.5504 * * *$ & 0.0004 & 0.0379 \\
May & 1.7326 & 0.083 & 0.0212 & $2.1302^{*}$ & 0.0332 & 0.0186 & $2.9823 * *$ & 0.0029 & 0.0267 \\
June & 1.3633 & 0.173 & 0.0111 & $2.0166^{*}$ & 0.0437 & 0.0158 & $2.6699 * *$ & 0.0076 & 0.0262 \\
July & $3.6924 * * *$ & 0.000 & 0.0221 & $3.3515^{* * *}$ & 0.0008 & 0.0220 & $3.8628^{* * *}$ & 0.0001 & 0.0397 \\
Aug. & $2.045^{*}$ & 0.041 & 0.0205 & $2.2438^{*}$ & 0.0248 & 0.0219 & $3.5788^{* * *}$ & 0.0003 & 0.0358 \\
Sept. & $2.1586^{*}$ & 0.031 & 0.0211 & $2.8119^{* *}$ & 0.0049 & 0.0258 & $2.6699 * *$ & 0.0076 & 0.0267 \\
Oct. & $2.045^{*}$ & 0.041 & 0.0328 & $2.4995^{*}$ & 0.0124 & 0.0324 & $2.8119 * *$ & 0.0049 & 0.0417 \\
Nov. & $2.5847^{* *}$ & 0.010 & 0.0412 & $2.3858^{*}$ & 0.0170 & 0.0344 & $3.2379 * *$ & 0.0012 & 0.0466 \\
\hline
\end{tabular}




\begin{tabular}{lccccccccc}
\hline Dec. & 1.1929 & 0.233 & 0.0252 & 0.93729 & 0.3486 & 0.0195 & $2.1018^{*}$ & 0.0356 & 0.0455 \\
Annual & $2.8119 * *$ & 0.005 & 0.0282 & $2.4995^{*}$ & 0.0124 & 0.0259 & $3.8912 * * *$ & 0.0001 & 0.0304 \\
\hline *. Is statistically significant at $P<0.05$ & **. Is statistically significant at $P<0.01$ & $* * *$. Is statistically significant at $P<0.001$
\end{tabular}

\section{Variability and Trends in Rainfall by AEZs}

The mean annual, seasonal and monthly rainfall for 35 years (1979-2013) at highland, midland and lowland AEZs of NSAZ is shown in Table 8 and 9. The annual rainfall performance was very much variable from year to year in the three AEZs. The yearly rainfall amount varies between 186.0-584.1mm, 375.8-1006.5mm and 921.6-2019.2mm over Kolla, Woina Dega and Dega AEZs, respectively. The mean annual rainfall was $1520.4 \mathrm{~mm}, 710.6 \mathrm{~mm}$ and $407.9 \mathrm{~mm}$ for highland, midland and lowland AEZs, respectively. The CV ranges from $15.95 \%$ in the Dega AEZ to $20.8 \%$ in the Kolla AEZ, suggesting high inner-annual rainfall variability in the latter AEZ. All the three AEZs received their maximum annual rainfall in 1998 and minimum in 2002 (Table 8). These were, therefore, the wettest and the driest years.

Table 8. Annual Rainfall Variability by AEZs (1979-2013)

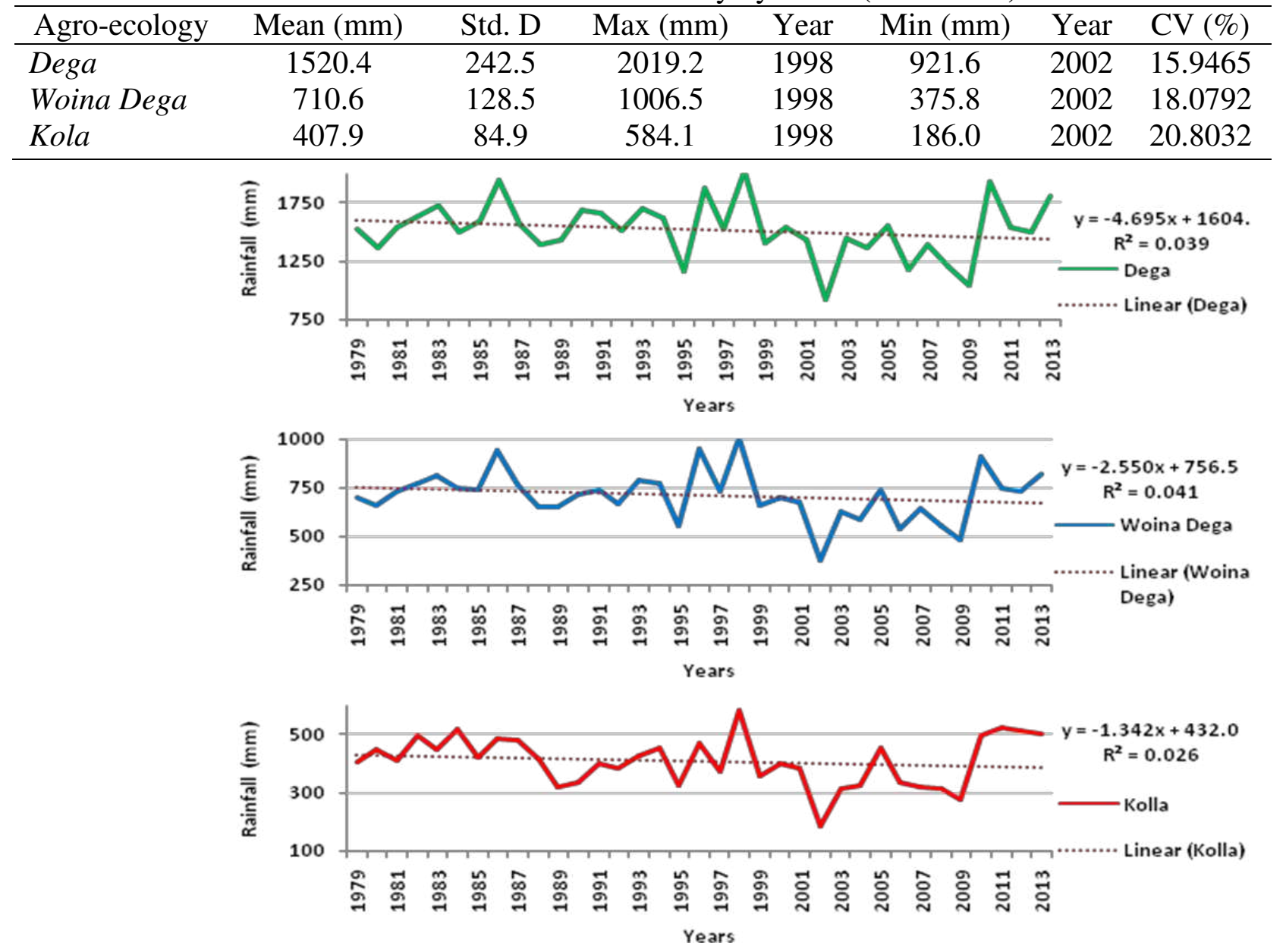

Figure 6. Trends in Mean Annual Rainfall by AEZs (1979 - 2013) 
Table 9. Monthly, Seasonal and Annual Rainfall Variability by AEZs (1979-2013)

\begin{tabular}{|c|c|c|c|c|c|c|c|c|c|c|c|c|c|c|c|c|c|c|}
\hline \multirow[t]{2}{*}{ Month } & \multicolumn{6}{|l|}{ Dega } & \multicolumn{6}{|c|}{ Woina Dega } & \multicolumn{6}{|l|}{ Kolla } \\
\hline & $\begin{array}{c}\text { Min } \\
(\mathrm{mm})\end{array}$ & $\begin{array}{c}\text { Max } \\
(\mathrm{mm})\end{array}$ & $\begin{array}{l}\text { Mean } \\
(\mathrm{mm})\end{array}$ & $\%$ & Std.D & $\begin{array}{l}\text { CV } \\
(\%)\end{array}$ & $\begin{array}{c}\text { Min } \\
(\mathrm{mm})\end{array}$ & $\begin{array}{c}\text { Max } \\
(\mathrm{mm})\end{array}$ & $\begin{array}{l}\text { Mean } \\
(\mathrm{mm})\end{array}$ & $\%$ & Std.D & $\begin{array}{l}\text { CV } \\
(\%)\end{array}$ & $\begin{array}{c}\text { Min } \\
(\mathrm{mm})\end{array}$ & $\begin{array}{c}\text { Max } \\
(\mathrm{mm})\end{array}$ & $\begin{array}{l}\text { Mean } \\
(\mathrm{mm})\end{array}$ & $\%$ & Std.D & $\begin{array}{l}\mathrm{CV} \\
(\%)\end{array}$ \\
\hline Jan. & 0.0 & 71.1 & 17.3 & 1.1 & 17.3 & 100 & 0.0 & 15.3 & 4.7 & 0.7 & 4.4 & 94 & 0.0 & 3.6 & 0.8 & 0.2 & 1.1 & 128 \\
\hline Feb. & 0.0 & 124.0 & 29.9 & 2.0 & 33.6 & 112 & 0.0 & 37.5 & 7.9 & 1.1 & 9.5 & 121 & 0.0 & 16.6 & 2.4 & 0.6 & 3.8 & 161 \\
\hline Mar. & 0.3 & 246.0 & 68.9 & 4.5 & 52.0 & 75 & 0.1 & 95.0 & 23.6 & 3.3 & 19.7 & 84 & 0.0 & 55.3 & 10.9 & 2.7 & 13.7 & 126 \\
\hline Apr. & 8.0 & 195.3 & 85.2 & 5.6 & 54.0 & 63 & 1.9 & 57.3 & 24.9 & 3.5 & 17.5 & 70 & 0.0 & 35.4 & 9.4 & 2.3 & 10.4 & 112 \\
\hline May & 1.9 & 193.9 & 67.8 & 4.5 & 56.5 & 83 & 0.3 & 95.2 & 28.2 & 4.0 & 27.5 & 97 & 0.0 & 79.0 & 12.5 & 3.1 & 19.2 & 154 \\
\hline Jun. & 44.5 & 421.2 & 195.6 & 12.9 & 81.2 & 42 & 18.2 & 204.8 & 88.4 & 12.4 & 42.0 & 48 & 3.6 & 125.1 & 37.7 & 9.2 & 24.6 & 65 \\
\hline July & 199.1 & 604.8 & 423.6 & 27.9 & 73.8 & 17 & 76.7 & 288.0 & 214.9 & 30.2 & 42.5 & 20 & 41.2 & 223.2 & 141.0 & 34.6 & 37.1 & 26 \\
\hline Aug. & 299.5 & 583.1 & 400.5 & 26.3 & 68.6 & 17 & 145.2 & 331.5 & 210.1 & 29.6 & 42.3 & 20 & 77.0 & 237.2 & 145.9 & 35.8 & 32.5 & 22 \\
\hline Sept. & 72.4 & 276.9 & 178.0 & 11.7 & 50.2 & 28 & 22.8 & 134.5 & 84.5 & 11.9 & 27.4 & 32 & 7.2 & 81.3 & 39.7 & 9.7 & 17.6 & 44 \\
\hline Oct. & 0.1 & 158.6 & 36.4 & 2.4 & 37.9 & 104 & 0.0 & 81.6 & 17.5 & 2.5 & 19.4 & 111 & 0.0 & 32.8 & 6.3 & 1.5 & 8.7 & 138 \\
\hline Nov. & 0.1 & 55.2 & 9.5 & 0.6 & 14.8 & 156 & 0.0 & 20.6 & 3.6 & 0.5 & 5.6 & 156 & 0.0 & 7.2 & 1.0 & 0.2 & 2.1 & 209 \\
\hline Dec. & 0.0 & 31.6 & 7.8 & 0.5 & 8.9 & 115 & 0.0 & 9.7 & 2.3 & 0.3 & 2.6 & 111 & 0.0 & 2.3 & 0.4 & 0.1 & 0.6 & 147 \\
\hline Belg & 82.3 & 535.1 & 251.8 & 16.6 & 111.7 & 44 & 28.9 & 190.9 & 84.7 & 11.9 & 42.4 & 50 & 3.5 & 114.5 & 35.1 & 8.6 & 27.6 & 79 \\
\hline Kiremt & 761.7 & 1513.8 & 1197.7 & 78.8 & 172.0 & 14 & 330.7 & 823.3 & 597.9 & 84.1 & 99.6 & 17 & 170.5 & 494.6 & 364.3 & 89.3 & 68.2 & 19 \\
\hline Annual & 921.6 & 2019.2 & 1520.4 & 100 & 242.5 & 16 & 375.7 & 1006.5 & 710.6 & 100 & 128.5 & 18 & 186.0 & 584.1 & 407.9 & 100 & 84.9 & 21 \\
\hline
\end{tabular}


All AEZs of the study area, as with most other places in Ethiopia, receive large amount of rainfall during summer (Kiremt) season, which contributes $78.8 \%, 84.1 \%$ and $89.3 \%$ of rainfall for Dega, Woina Dega and Kolla AEZs, respectively. Belg also contributes $16.6 \%, 11.9 \%$ and $8.6 \%$ of rainfall for each, respectively. While rainfall was more concentrated in Kiremt season at lowland AEZ than others, Belg contributed more amount of rain for highland AEZ than for others. The mean monthly maximum rainfall was $423.6 \mathrm{~mm}, 214.9 \mathrm{~mm}$ and $145.9 \mathrm{~mm}$ at Dega, Woina Dega and Kolla AEZs, respectively. While highland and midland AEZs get their maximum amount of rainfall on July, lowland receives its maximum amount of rainfall on August. All AEZs of the study receive limited/ minimum amount of rain on December (Table 9). Figure 6 and Table 10 show the trend test results of rainfall on the annual time scale. Though not statistically significant, a decreasing trend was observed at all AEZs. The rate of decline was $4.695 \mathrm{~mm} /$ year, $2.55 \mathrm{~mm} /$ year and $1.342 \mathrm{~mm} / \mathrm{year}$ in Dega, Woina Dega and Kolla AEZs, respectively. This result partly goes in line with the finding by Befikadu et al. (2019).

Table 10. M-K Test and Sen's Slope on Monthly, Seasonal and Annual Rainfall by AEZs (1979-2013)

\begin{tabular}{|c|c|c|c|c|c|c|c|c|c|}
\hline \multirow[t]{2}{*}{ Month } & \multicolumn{3}{|l|}{ Dega } & \multicolumn{3}{|c|}{ Woina Dega } & \multicolumn{3}{|l|}{ Kolla } \\
\hline & $\mathrm{Z}(\mathrm{M}-\mathrm{K})$ & P-Value & Slope & $\mathrm{Z}(\mathrm{M}-\mathrm{K})$ & P-Value & Slope & $\mathrm{Z}(\mathrm{M}-\mathrm{K})$ & P-Value & Slope \\
\hline Jan. & -0.8521 & 0.3942 & -0.1535 & -0.5397 & 0.5894 & -0.0235 & -1.3496 & 0.1771 & -0.0104 \\
\hline Feb. & $-2.5847 * *$ & 0.0098 & -1.2546 & $-2.7267 * *$ & 0.0064 & -0.2968 & $-2.0468 * *$ & 0.0407 & -0.0203 \\
\hline Mar. & -1.1645 & 0.2442 & -0.8473 & -0.426 & 0.6701 & -0.1116 & -0.7385 & 0.4602 & -0.0752 \\
\hline Apr. & 0.08521 & 0.9321 & 0.0588 & -0.1136 & 0.9095 & -0.0261 & -0.3976 & 0.6909 & -0.0501 \\
\hline May & -0.284 & 0.7764 & -0.2453 & -0.142 & 0.8871 & -0.0155 & 0.14201 & 0.8871 & 0.0149 \\
\hline June & $-2.329 * *$ & 0.0199 & -2.6004 & -1.903 & 0.0570 & -1.0714 & -1.3349 & 0.1819 & -0.5467 \\
\hline July & 0.65327 & 0.5136 & 0.9351 & 0.85209 & 0.3942 & 0.6685 & 1.1361 & 0.2559 & 0.5927 \\
\hline Aug. & 0.68167 & 0.4954 & 0.9781 & -0.9941 & 0.3202 & -0.8087 & -1.6758 & 0.0938 & -0.9650 \\
\hline Sept. & -0.6249 & 0.5321 & -0.5528 & -0.7385 & 0.4602 & -0.3630 & -1.1645 & 0.2442 & -0.2267 \\
\hline Oct. & -0.9373 & 0.3486 & -0.2674 & -0.7385 & 0.4602 & -0.1258 & -0.412 & 0.6803 & -0.0273 \\
\hline Nov. & 0.9657 & 0.3342 & 0.0479 & 0.76688 & 0.4432 & 0.0187 & 1.0112 & 0.3119 & 0.0012 \\
\hline Dec. & -0.0284 & 0.9773 & -0.0023 & 0 & 1.0000 & -0.0001 & -0.3276 & 0.7432 & -0.0002 \\
\hline Belg & -1.6474 & 0.0995 & -3.5381 & -1.2781 & 0.2012 & -0.6940 & -1.3633 & 0.1728 & -0.5819 \\
\hline Kiremt & -0.2556 & 0.7982 & -0.6531 & -0.8805 & 0.3786 & -1.0811 & -0.9373 & 0.3486 & -1.3955 \\
\hline Annual & -1.1077 & 0.2680 & -4.7715 & -1.2497 & 0.2114 & -2.3478 & -1.1929 & 0.2329 & -2.2691 \\
\hline
\end{tabular}

Table 11 depicts frequency and percentage of annual and seasonal PCI values by agro-ecology for the years ranging from 1979 to 2013. It shows irregular distributions in the annual rainfall patter at all AEZs. While higher frequency of irregular distributions in the annual rainfall patter was seen at Dega agro-ecology (48.6\%), more strong irregularity was observed at Woina Dega $(82.9 \%)$ and Kolla $(97.1 \%)$. Table 11 also illustrates a more or less uniform and moderate pattern in Kiremt rainfall at all agro-ecologies. It further shows that an increase in the irregularity of Belg rainfall pattern as on moves from Dega down to Kolla AEZs.

Table 11. Percentage of Annual and Seasonal PCI Values by AEZs (1979-2013)

\begin{tabular}{lccccccccc}
\hline \multirow{2}{*}{ PCI } & Dega & \multicolumn{9}{c}{ Woina Dega } & \multicolumn{5}{c}{ Kolla } \\
\cline { 2 - 10 } & Annual & Kiremt & Belg & Annual & Kiremt & Belg & Annual & Kiremt & Belg \\
\hline$\leq 10$ & - & $62.9 \%$ & $20 \%$ & - & $51.4 \%$ & $8.6 \%$ & - & $11.4 \%$ & - \\
$(10-15]$ & $2.9 \%$ & $37.1 \%$ & $51.4 \%$ & - & $48.6 \%$ & $62.9 \%$ & - & $82.9 \%$ & $37.1 \%$ \\
$(15-20]$ & $48.6 \%$ & - & $20 \%$ & $17.1 \%$ & - & $25.7 \%$ & $2.9 \%$ & $5.7 \%$ & $40 \%$ \\
$>20$ & $48.6 \%$ & - & $8.6 \%$ & $82.9 \%$ & - & $2.9 \%$ & $97.1 \%$ & - & $22.9 \%$ \\
\hline
\end{tabular}


Figure 7 shows SRA computed for mean annual rainfall in three agro-ecological belts in NSAZ. The upward bar shows positive anomalies and the downward bar shows negative anomalies during the 35 years (1979-2013) of the study. Figure 7 reveals negative rainfall anomalies for 16 years in both Dega and Woina Dega AEZs and for 18 years in Kolla AEZ between 1979 and 2013. During those years annual rainfall was below average. The reduced precipitation, shown in the aforementioned figure as negative rainfall anomalies, has a critical implication on rural livelihoods ingeneral and food security in particular. Figure 7 also illustrates positive rainfall anomaly for 19 years in both Dega and Woina Dega AEZs and for 17 years in Kolla AEZ during the study period and this implies that during those years their respective annual rainfall was above average in each belts.
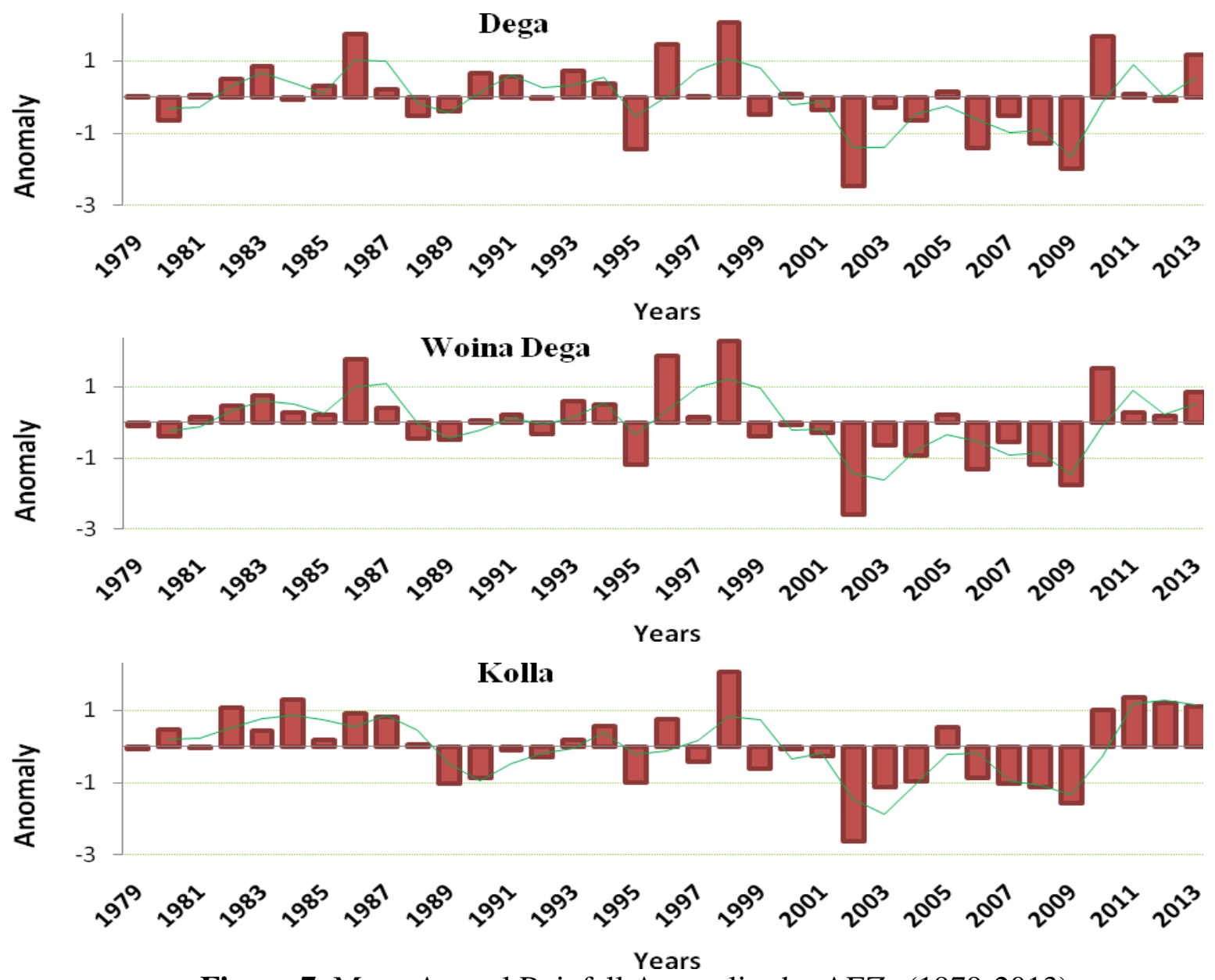

Figure 7. Mean Annual Rainfall Anomalies by AEZs (1979-2013)

SRA, apart from enabling to identify the dry and wet years in the record, is important for drought monitoring. Using SRA, as Befikadu et al. (2019) plainly indicated, severity of drought is categorized as: extreme drought (SRA $<-1.65)$, severe drought $(-1.28>$ SRA $>-1.65)$, moderate drought $(-0.84>$ SRA $>-1.28)$, and no drought $($ SRA $>-0.84)$ Table 12 summarizes the frequency and severity of droughts in the study area for the years between 1979 and 2013. It shows high frequency of drought in Kolla agro-ecology (28.6\%), which experienced drought once in every three or four years between 1979 and 2013. Dega and Woina Dega experienced drought less frequently $(\leq 17.1 \%)$ than Kolla. 
Table 12. Percentage and Severity of Drought by AEZs (1979-2013)

\begin{tabular}{lcccc}
\hline Agro-Ecology & $\begin{array}{c}\text { Extreme Drought } \\
\text { (SRA }<-1.65)\end{array}$ & $\begin{array}{c}\text { Severe Drought } \\
(-1.65 \leq \text { SRA } \leq-1.28)\end{array}$ & $\begin{array}{c}\text { Moderate Drought } \\
(-1.28 \leq \text { SRA } \leq-0.84)\end{array}$ & $\begin{array}{c}\text { No Drought } \\
\text { (SRA }>-0.84)\end{array}$ \\
\hline Dega & $5.7 \%$ & $8.6 \%$ & 0 & $85.7 \%$ \\
Woina Dega & $5.7 \%$ & $2.9 \%$ & $8.6 \%$ & $82.9 \%$ \\
Kolla & $2.9 \%$ & $2.9 \%$ & $22.9 \%$ & $71.4 \%$ \\
\hline
\end{tabular}

\section{Potential Impacts of Rainfall and Temperature Variability}

The study area's economy mainly depends on rain-fed agricultural activities. It is intimately tied to the prevailing weather conditions. The occurrences of temperature and rainfall variability would compromise the productive performances of the agricultural sector and makes rural households at risk. Variations and fluctuations in rainfall and temperature repetitively bring devastating repercussions on livestock and crop productions of the area (Million 2007; Messay 2009; Meskerem 2011; Feleke 2018). The productivity of livestock is being adversely affected, among others, through shortages of rain. Deficiency of rain is usually associated with reduced pastures and limited pasture inturn is associated with death of cattle. Loss of livestock holding consequently exposes rural households, who depend on cattle for survival, to food insecurity. It more specifically makes income earning from livestock raring very low and limits the purchasing capacity of the households to have access to food. Erratic rainfall is also responsible for crop failures and apparently reduces productions. The decline in agricultural yield slowly drains food stocks and increases the risk of hunger.

This study has shown prevalence of erratic climatic conditions within NSAZ. The area is prone to extreme climatic events particularly drought, flooding, water-logging and frost. Kolla AEZ of the area experienced drought once in every 3 or 4 years between 1979 and 2013. During extreme drought conditions, it is common that many smallholder farmers could not adequately feed their family members from own production. They depend on food aid (could be from the government or their relatives or NGOs) to sustain their lives or die due to hunger (Messay 2009). Million (2007) indicated that water-logging in Woin Dega and frost in Dega AEZs devastate 50 to $75 \%$ of standing crops during their worst incidence. Kassahun (2011) showed that change of rainfall amount and pattern significantly reduce total crop yield through affecting planting time, growing stages, and harvesting periods. Sumelius et al. (2009) indicated that as high as $80 \%$ of the variability in agricultural production is caused by the disturbance of weather and related factors. Von Braun (1991) further showed that a 10\% decrease in the amount of rainfall below the long run average leads to a $4.4 \%$ reduction in the production of food and makes rural households vulnerable to food insecurity. Bewket (2009) complemented that extreme variability of rainfall is a major cause of variations in crop production making smallholder farmers susceptible to food shortage.

The increasing trend of annual and seasonal temperature over the study period could also have an influence on smallholder farmers and their crop production processes (Parry et al. 2007). Feleke (2018) indicated extreme temperature as one of the principal factors behind crop production failure across Dega, Woina Dega and Kolla AEZs in Kuyu district of NSAZ. He also indicated that crop yield dropped when the threshold of temperature values for a crop in a given region is exceeded only. This indicated that crop production failed when temperature became above or below the potential of the crop in any AEZ. Funk et al. (2012) reported that warming would 
increase the influence of droughts, reducing the moisture availability of the soil affecting the productivity of the cropland. Gebreegziabher et al. (2013) also indicated that an increase in annual and seasonal temperature decreases crop yields per hectare. It is estimated that a $1^{\circ} \mathrm{C}$ rise in annual temperature will lead to a reduction of yields that costs about 1577.00 Ethiopian Birr from crop production. EPCC (2015) and Pachauri et al. (2014) showed that an increase in temperature could have potential influence on crop production differently. This could be through the occurrences of crop pests such as insects, migratory birds, and rodents, and invasive weeds that occur at some stage in the agricultural calendar (Abebe and Arega 2019).

In a nut shell, the potential influence of climate variability on crop production would be its sensitivity mainly to the variability of rainfall and temperature. This is because crop productions have very limited optimal and tolerable rainfall and temperature range to grow well (Kassahun 2011; Gebreegziabher et al. 2013). The occurrences of temperature and rainfall variability would drastically reduce crop production and in certain circumstances cause overall crop failure (Funk et al. 2015). Temperature and rainfall variability reduce crop production in particular and affect the overall success of the agricultural sector in general. At times when climate variability becomes the worst, it results in total crop failure leading to hunger and death of people and animals (Abebe and Arega 2019).

\section{Conclusion}

This study has analyzed climate variability over three AEZs in Central Ethiopia. The analyzed historical long term climate data shows that there was variability in rainfall and temperature from year to year over the three AEZs of the study area. The detected rainfall and temperature variability has critical implications for rural livelihoods in general and, rain-fed agriculture and food security in particular. Variations and fluctuations in rainfall and temperature compromise, among others, the productive performances of the agricultural sector and makes rural households at risk. Rainfall and temperature variability will continually compromise the life of rural people if not halted. There is the need for an increased attention on adaptation and mitigation mechanisms. The impact of climate variability varies based on rural households' ability to respond for and mitigate its adverse effects. Variations in climate elements disproportionately affect poor rural households. Any effort to be exerted by the government or else any other concerned bodies should have to consider the magnified impact of climate variability on the most vulnerable group of the society. Rainfall and temperature variability and their resultant effect on rural livelihoods imply those poor farmers who are dependent on natural weather condition need protection through for example, irrigation scheme, introduction of drought resistant varieties of crops, livelihood diversifications and other services. This can help farmers to stabilize income during the period of low rain and poor output.

\footnotetext{
Abbreviations

AEZs: Agro-Ecological Zones; CV: Coefficient of Variation; IPCC: Intergovernmental Panel on Climate Change; MK: Mann Kendal; NMA: National Meteorological Service Agency; NSAZ: North Shewa Administrative Zone; ONRS: Oromia National Regional State; PCI: Precipitation Concentration Index; SD: Standard Deviation; SRA: Standardized Rainfall Anomalies. Acknowledgments

We are grateful to the Ethiopian National Meteorological Agency for providing us gridded rainfall and temperature data.
} 


\section{Authors' Contributions}

The first author collected and analyzed the data, and wrote the manuscript. All authors read, edited and approved the manuscript.

\section{Funding}

The first author is grateful to Ambo and Arba Minch Universities for funding support while undertaking his $\mathrm{PhD}$ study.

\section{Availability of Data and Materials}

The datasets used and/or analyzed during the current study are available from the corresponding author on reasonable request.

\section{Competing Interests}

The authors declare that they have no competing interests.

\section{References}

Abebe A and Arega B (2019) Spatiotemporal Variability and Trends of Rainfall and Temperature in the Northeastern Highlands of Ethiopia. Modeling Earth Systems and Environment (2020) 6:285-300.

Al-Shamarti HKA (2016) The Variation of Annual Precipitation and Precipitation Concentration Index of Iraq. IOSR J Appl Phys 8(4):36-44. https ://doi.org/10.9790/4861-08040 33644

Asaminew T and Diriba K (2015) Recent Changes in Rainfall, Temperature and Number of Rainy Days over Northern Oromia Zone, Ethiopia Science Discovery.Vol.3, No. 6, 2015, pp. 62-70.

Asfaw A, Simane B, Hassen A and Bantider A (2018) Variability and Time Series Trend Analysis of Rainfall and Temperature in North Central Ethiopia: A Case Study in Woleka Sub-Basin. Weather Clim Extrem 19:29-41. https ://doi.org/10.1016/j.wace.2017.12.002.

Astawsegn Z (2014) Effects of Climate Change and Variability on Rural Livelihoods and Responses: The Case of Soro Woreda, Hadiya Zone, SNNPR. MA Thesis in Climate Change and Adaptation. Addis Ababa University, Ethiopia.

Ayalew D, Tesfaye K, Mamo G, Yitaferu B and Bayu W (2012) Variability of Rainfall and Its Current Trend in Amhara Region. Ethiopia. Afr J Agric Res 7(10):1475-1486.

Befikadu E, Belay S, Ermias T, Victor O and Nigussie T (2019) Climate Variability and Farmers' Perception in Southern Ethiopia. Advances in Meteorology. Volume 2019, Article ID 7341465, 19 pages, Hindawi, https://doi.org/10.1155/2019/7341465

Bewket W (2009) Rainfall Variability and Crop Production in Ethiopia: Case Study in the Amhara Region. In: Proceedings of the 16th International Conference of Ethiopian Studies. Trondheim: Norwegian University of Science and Technology, Vol. 3, pp.823-836

Bewket W and Conway D (2007) "A Note on the Temporal and Spatial Variability of Rainfall in the Drought-Prone Amhara Region of Ethiopia," International Journal of Climatology, vol. 27, no. 11, pp. 1467-1477, 2007.

Chakraborty S, Pandey RP, Chaube UC and Mishra SK (2013) Trend and Variability Analysis of Rainfall Series at Seonath River Basin, Chhattisgarh (India). Int J Appl Sci Eng Res 2(4):425-434.

Chattopadhyay S and Edwards DR (2016) Long-Term Trend Analysis of Precipitation and Air Temperature for Kentucky, United States. Climate 4(1):10. https ://doi.org/10.3390/cli40 10010

Conway D (2000a) Some Aspects of Climate Variability in the North East Ethiopian Highlands-Wollo and Tigray. Sinet 23(2):139-161

Conway D (2000b) The Climate and Hydrology of the Upper Blue Nile River. Geogr J 166(1):49-62. Conway D, Mould C, Bewket W. 2004. Over One Century of Rainfall and Temperature Observations in Addis Ababa, Ethiopia. Int J Climatol 24(1):77-91.

De Luis M, Gonzalez-Hidalgo JC, Brunetti M and Longares LA (2011) Precipitation Concentration Changes in Spain 1946-2005. Nat Hazards Earth Syst Sci 11(5):1259.

Easterling WE, Aggarwal PK, Batima P, Brander KM, Erda L, Howden SM and Tubiello FN (2007) Food, fiber and forest products: impacts, adaptation and vulnerability. Contribution of Working 
Group II to the Fourth Assessment Report of the Intergovernmental Panel on Climate Change. Cambridge University Press, Cambridge, UK, pp 273-313

Ethiopian Panel on Climate Change/EPCC (2015) First Assessment Report, Working Group II Agriculture and Food Security, Published By the Ethiopian Academy of Sciences

Fekadu K (2015) Ethiopian Seasonal Rainfall Variability and Prediction Using Canonical Correlation Analysis (CCA). Earth Sci 4(3):112-119. https ://doi.org/10.11648/j.earth .20150 403.14

Feleke Y M (2018) Determinants of Crop Production Failure in Kuyu Woreda, North Shoa, Oromia Regional State, Ethiopia. Food Science and Quality Management, Vol.72, ISSN 2224-6088 (Paper) ISSN 2225-0557 (Online www.iiste.org)

Feng G, Cobb S, Abdo Z, Fisher DK, Ouyang Y, Adeli A and Jenkins JN (2016) Trend Analysis and Forecast of Precipitation, Reference Evapo-transpiration, and Rainfall Deficit in the Black Land Prairie Of Eastern Mississippi. J Appl Meteorol Climatol 55(7):1425-1439.

Funk C, Nicholson SE, Landsfeld M, Klotter D, Peterson P and Harrison L (2015) The Centennial Trends Greater Horn of Africa Precipitation Dataset. Sci Data 2:150050

Gebreegziabher Z, Mekonnen M, Deribe R, Abera S and Kassahun MM (2013) Crop-livestock InterLinkages and Climate Change Implications for Ethiopia's Agriculture. Environment For Development, Discussion Paper Series EfD DP 13-14. Pp 32

Gebrehiwot TG and Veen A (2013) Assessing the Evidence of Climate Variability in the Northern Part of Ethiopia. J Dev Agric Econ 5(3):104-119. https ://doi.org/10.5897/JDAE1 2.056

Hulme M, Doherty RM, Ngara T, New MG and Lister D (2001) African Climate Change: 1900-2100. Climate Research 17(2): 145-168.

Jain SK and Kumar V (2012) Trend Analysis of Rainfall and Temperature Data for India. Curr Sci (Bangalore) 102(1):37-49. https ://www.jstor.org/stabl e/24080 385

Jury MR and Funk C (2013) Climatic Trends over Ethiopia: Regional Signals and Drivers. Int J Climatol 33(8):1924-1935. https ://doi.org/10.1002/joc.3560

Kassahun A (2011) The Impact of Climate Variability on Crop Production In Ethiopia: Which Crop Is More Vulnerable to Rainfall Variability? Addis Ababa: EEA/EEPRY.

Kebede G and Bewket W (2009) Variations in Rainfall and Extreme Event Indices in the Wettest Part of Ethiopia. SINET Ethiop J Sci 32(2):129-140

Kendall MG (1975) Rank Correlation Methods, 4th edn. Griffin, London

Kew S, Philip S, Van Oldenborgh GJ, Otto F, Haustein K, King A and Hailemariam K (2017) Challenges and Possibilities for Attribution Studies in Developing Countries: Ethiopian Drought of 2015. In: EGU General Assembly Conference Abstracts 19: 16869

Kinyangi J, Herrero MT, Omolo A, Steeg JVD and Thornton PK (2009) Scoping Study on Vulnerability to Climate Change and Climate Variability in the Greater Horn of Africa: Mapping Impacts and Adaptive Capacity.

Longobardi A and Villani P (2010) Trend Analysis of Annual and Seasonal Rainfall Time Series in the Mediterranean Area. Int J Climatol 30(10):1538-1546. Https: //doi.org/10.1002/joc.2001

Mann HB (1945) Nonparametric Tests against Trend. Econometrica 13:245-259. McSweeney C, New M, Lizcano G. 2008. United Nation Development Programme (UNDP) climate change country profiles-Ethiopia http://countryprofiles.geog.ox.ac.uk.

McSweeney C, New M, Lizcano G and Lu X (2010) The UNDP Climate Change Country Profiles Improving the Accessibility of Observed and Projected Climate Information for Studies of Climate Change in Developing Countries. Bulletin of the American Meteorological Society, 91, 157-166.

Mengistu D, Bewket W and Lal R (2014) Recent Spatiotemporal Temperature and Rainfall Variability and Trends over the Upper Blue Nile River Basin, Ethiopia. Int J Climatol 34(7):2278-2292.

Messay M T (2009) Causes of Rural Household Food Insecurity: A Case from Kuyu District, Central Ethiopia. Journal of Sustainable Development in Africa. Volume 11, No.4. ISSN: 1520-5509, Clarion University of Pennsylvania, Clarion, Pennsylvania. 
Meskerem A (2011) Household Food Security Situation in Girar Jarso Woreda, North Shewa Zone of Oromiya Region, Ethiopia. MSc Thesis in Food Security Studies, AAU, Ethiopia.

Meze-Hausken E (2004) Contrasting Climate Variability And Meteorological Drought With Perceived Drought And Climate Change In Northern Ethiopia. Clim Res 27(1):19-31.

Million G (2007) Livelihood Analysis: Vulnerability, Assets, Institutions and Strategies (The Case of Two Kebeles in Wuchale Woreda, Oromia Regional State). MA Thesis in Development Studies at Addis Ababa University, Ethiopia.

National Meteorological Agency of Ethiopia (NMA) (2007) Climate Change National Adaptation Programme of Action (NAPA) of Ethiopia, National Meteorological Services Agency, Ministry of Water Resources, Federal Democratic Republic of Ethiopia, Addis Ababa, Ethiopia.

Pachauri RK, Allen MR, Barros VR, Broome J, Cramer W, Christ R and Dubash NK (2014) Climate Change 2014: Synthesis Report. Contribution of Working Groups I, II and III to the Fifth Assessment Report of the Intergovernmental Panel on Climate Change (IPCC).

Parry M, Parry ML, Canziani O, Palutikof J, Van der Linden P and Hanson C (Eds.) (2007) Climate Change 2007-Impacts, Adaptation and Vulnerability: Working Group II Contribution to the Fourth Assessment Report of the IPCC (Vol. 4). Cambridge University Press, Cambridge

Poudel S and Shaw R (2016) The Relationships between Climate Variability and Crop Yield in a Mountainous Environment: A Case Study in Lamjung District, Nepal. Climate 4(1):13.

Regassa S, Givey C and Castillo G (2010) The Rain Doesn't Come on Time Anymore: Poverty, Vulnerability, and Climate Variability in Ethiopia. Oxfam Policy Pract Clim Change Resil 6(1):90134.

Rosell S and Holmer B (2007) Rainfall Change and Its Implications for Belg Harvest in South Wollo. Ethiopia. GeografiskaAnnaler Ser A Phys Geogr 89(4):287-299.

Sumelius J, Bäckman S, Kahiluoto H and Rötter R (2009) Sustainable Rural Development with Emphasis on Agriculture and Food Security within the Climate Change Setting: SARD-Climate Final Report. Helsinki

Suryabhagavan KV (2016) GIS-Based Climate Variability and Drought Characterization in Ethiopia over Three Decades. Weather Clim Extrem. https ://doi.org/10.1016/j.wace.2016.11.005

Svoboda M, Hayes M and Wood D (2012) Standardized Precipitation Index User Guide, World Meteorological Organization, Geneva, Switzerland.

Tekleab S, Mohamed Y and Uhlenbrook S (2013) "Hydro-Climatic Trends in the Abay/Upper Blue Nile Basin, Ethiopia," Physics and Chemistry of the Earth, Parts A/B/C, vol. 61-62, pp. 32-42, 2013.

Teyso TA and Anjulo A (2016) Spatiotemporal Variability and Trends of Rainfall and Temperature Over Gamo Gofa Zone. Ethiopia. J Sci Res Rep. https ://doi.org/10.9734/JSRR/2016/28667

Valli M, Sree KS and Krishna IVM (2013) Analysis of Precipitation Concentration Index and Rainfall Prediction in Various Agro-Climatic Zones of Andhra Pradesh, India. Int Res J Environ Sci 2(5):53-61

Viste E, Korecha D and Sorteberg A (2013) Recent Drought and Precipitation Tendencies in Ethiopia. Theoret Appl Climatol 112(3-4):535-551. https://doi.org/10.1007/s0070 4-012-0746-3

Von Braun, Joachim (1991) "A Policy Agenda for Famine Prevention in Africa”. Food Policy Reports 1. International Food Policy Research Institute (IFPRI). http://ideas.repec.org/p/fpr/fprepo/1.html.

Wagesho N, Goel NK and Jain MK (2013) Temporal and Spatial Variability of Annual and Seasonal Rainfall over Ethiopia. Hydrol Sci J 58(2):354-373. https ://doi.org/10.1080/02626 667.2012.75454 3

Wang W, Chen X, Shi P and Van Gelder PHAJM (2008) Detecting Changes in Extreme Precipitation and Extreme Stream Flow in the Dongjiang River Basin in Southern China. Hydrol Earth Syst Sci Discuss 12(1):207-221 
Figures

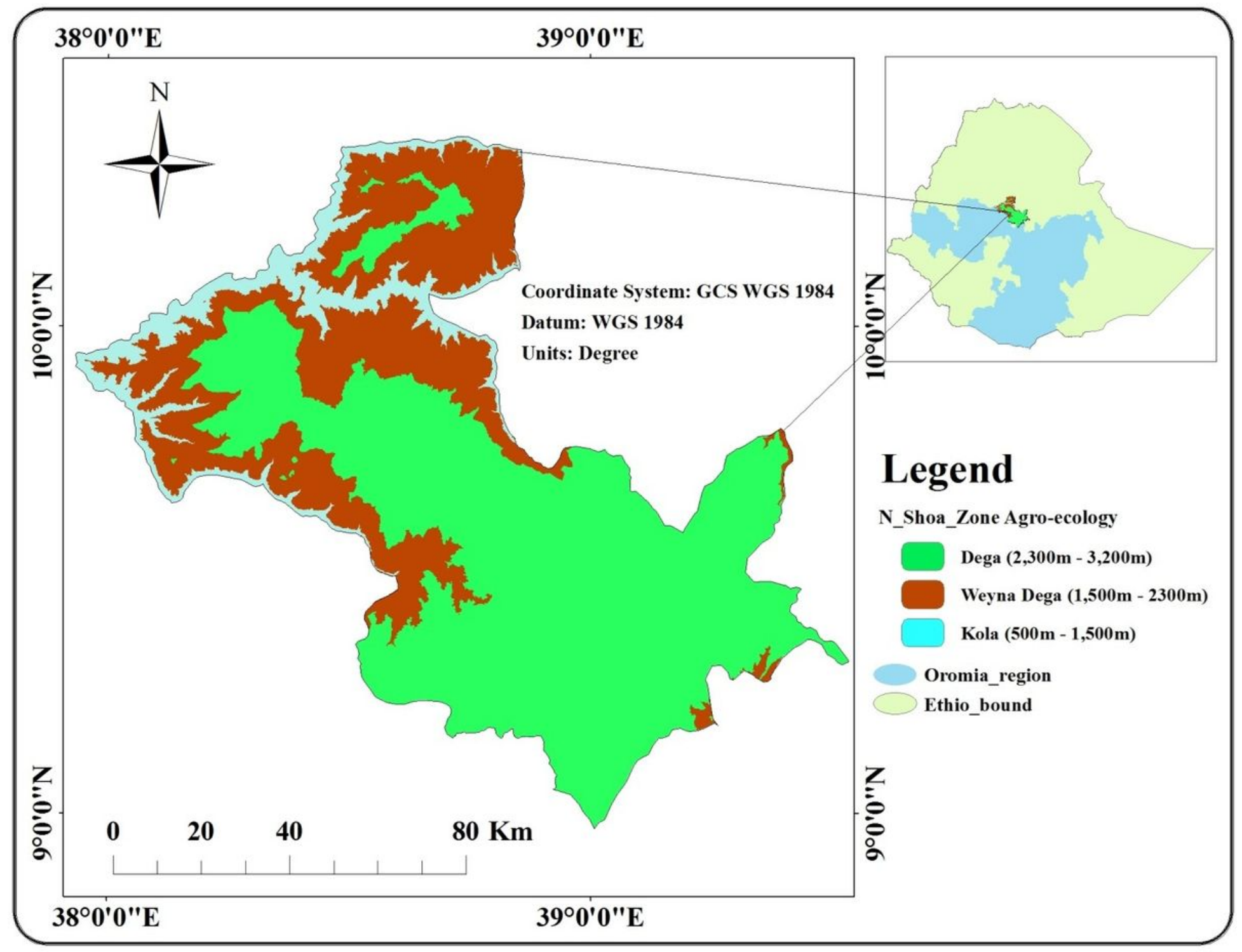

Figure 1

Location of the Study Area 

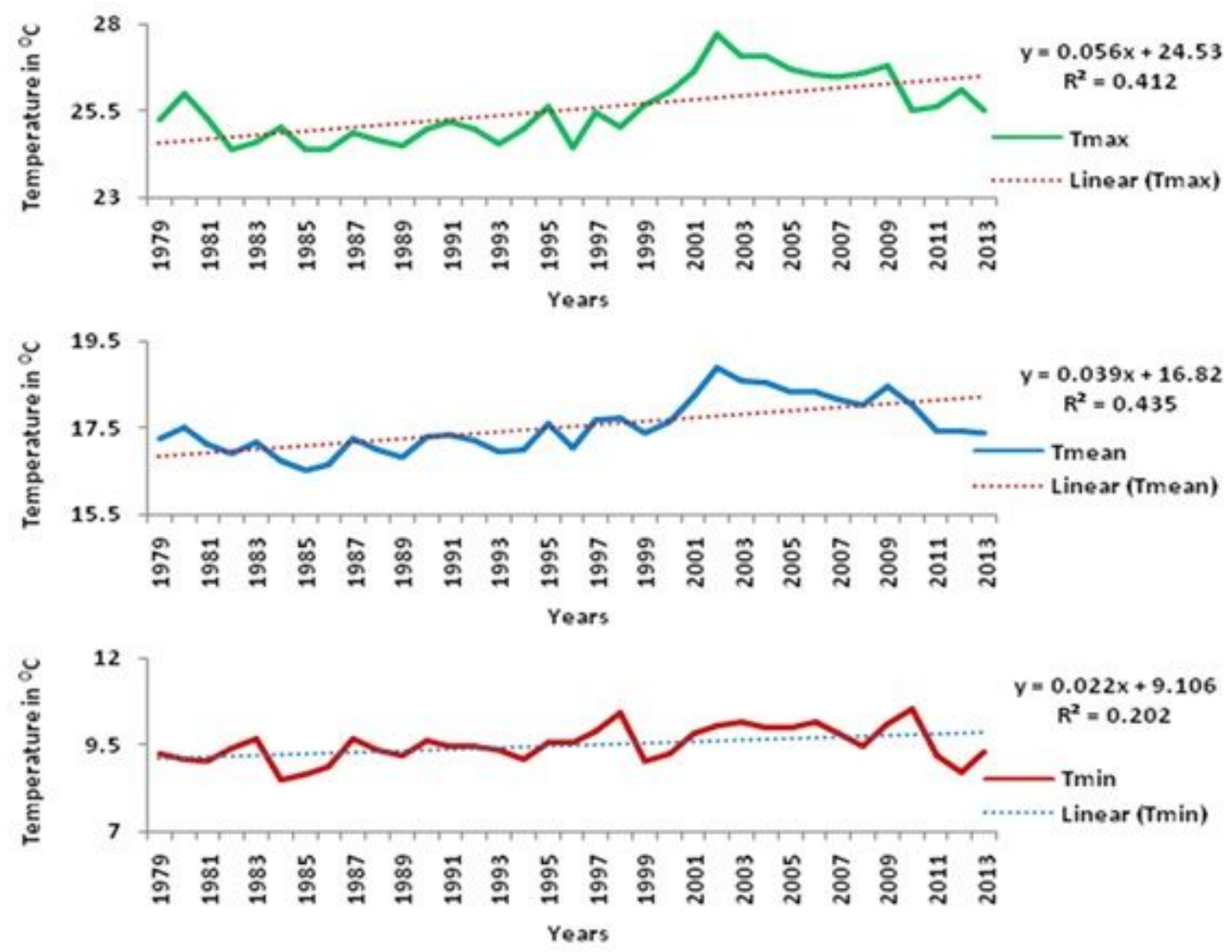

Figure 2

Trends in Long-Term Mean Annual Maximum, Minimum and Average Temperature 

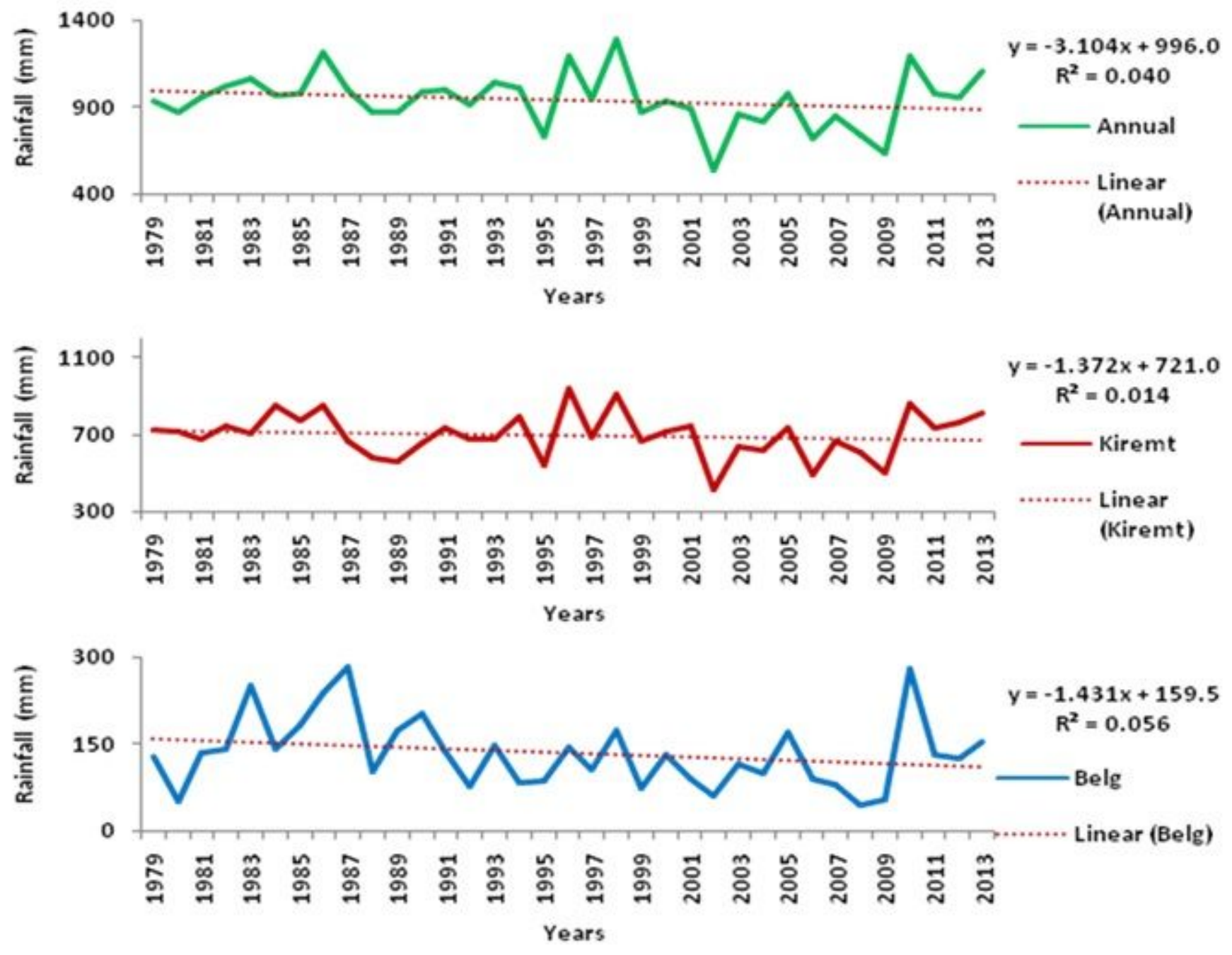

Figure 3

Trends in Mean Annual, Kiremt and Belg Rainfall (1979 - 2013) 

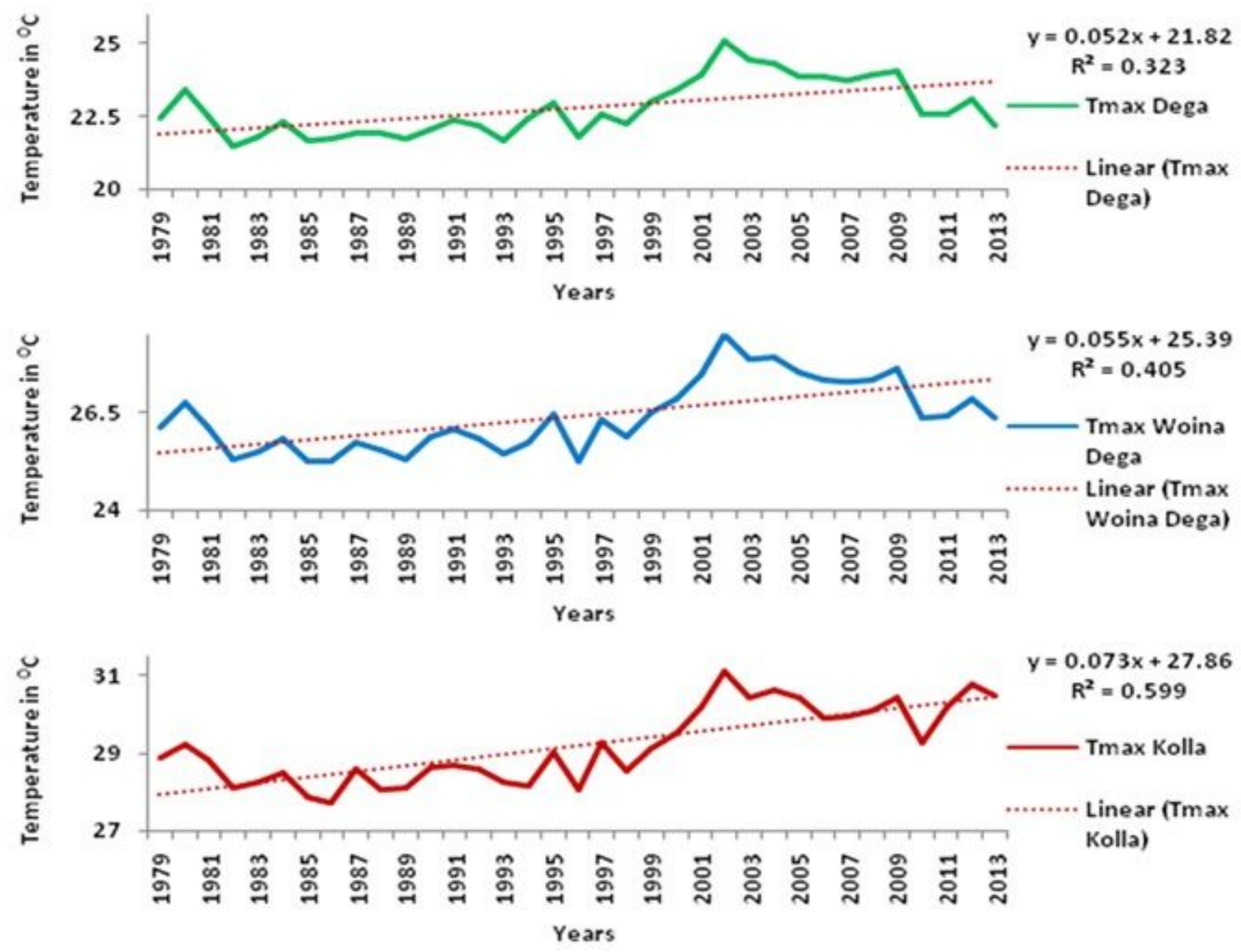

Figure 4

Trends in Mean Annual Maximum Temperatures by AEZs (1979 - 2013) 

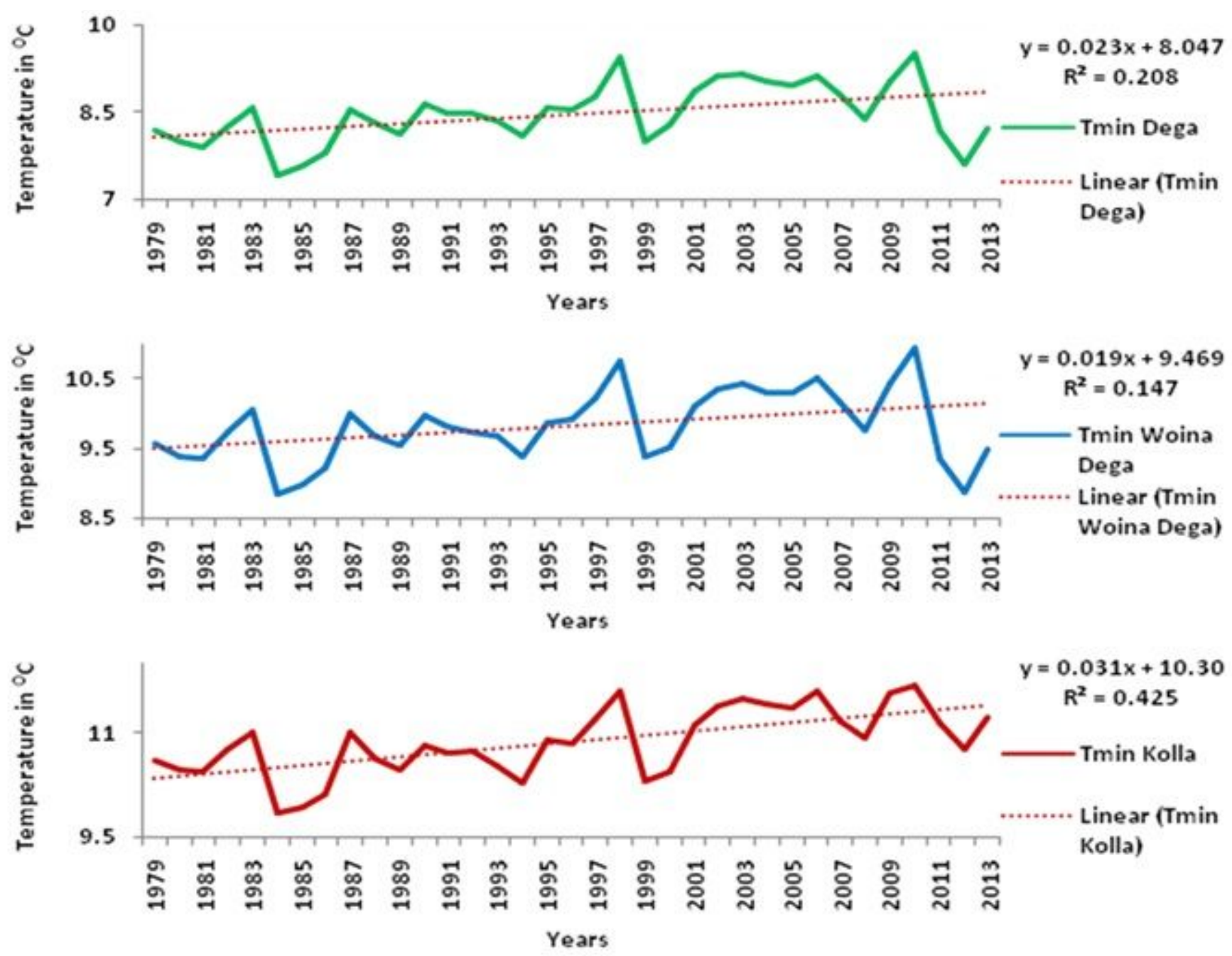

Figure 5

Trends in Mean Annual Minimum Temperatures by AEZs (1979 - 2013) 

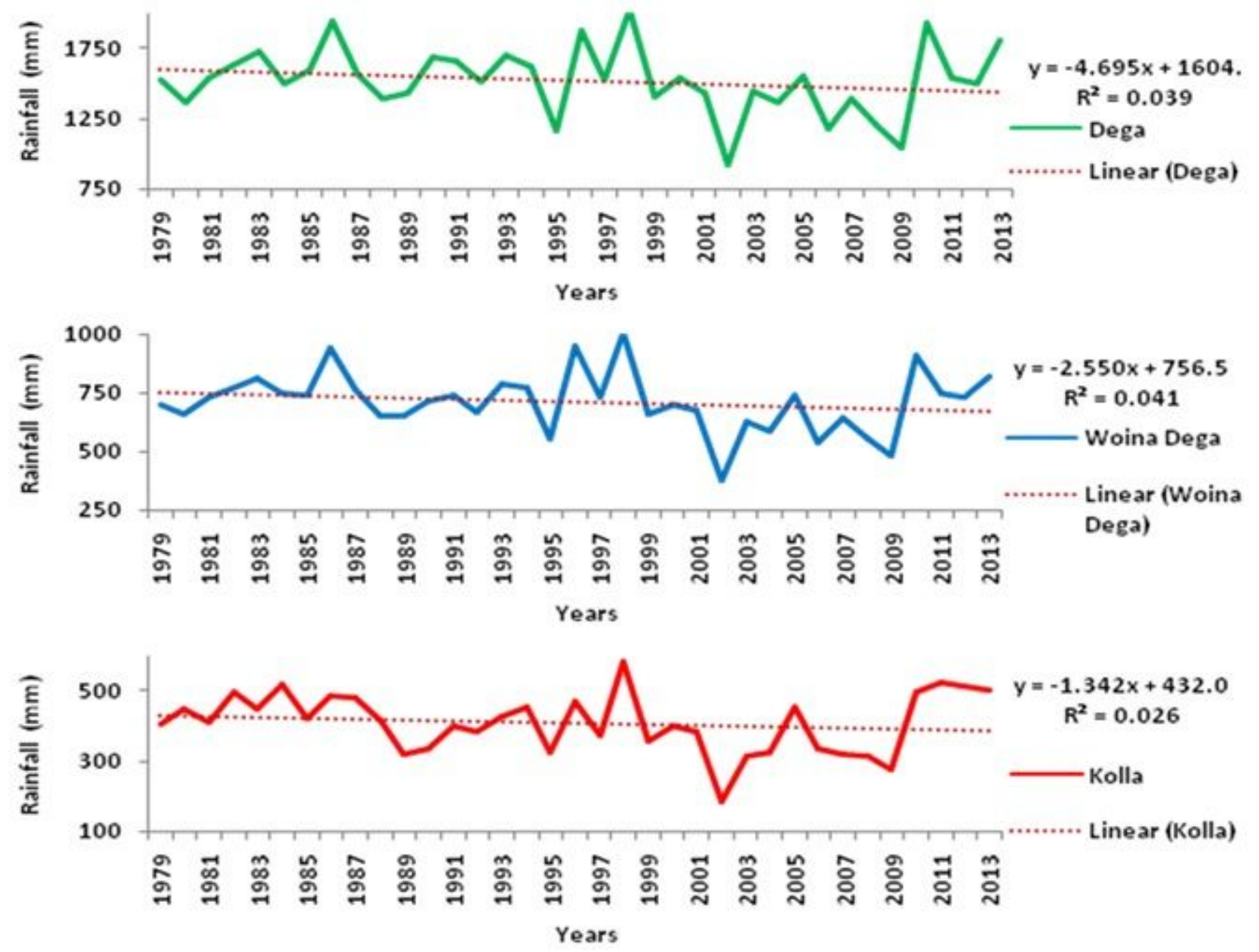

Figure 6

Trends in Mean Annual Minimum Temperatures by AEZs (1979 - 2013) 

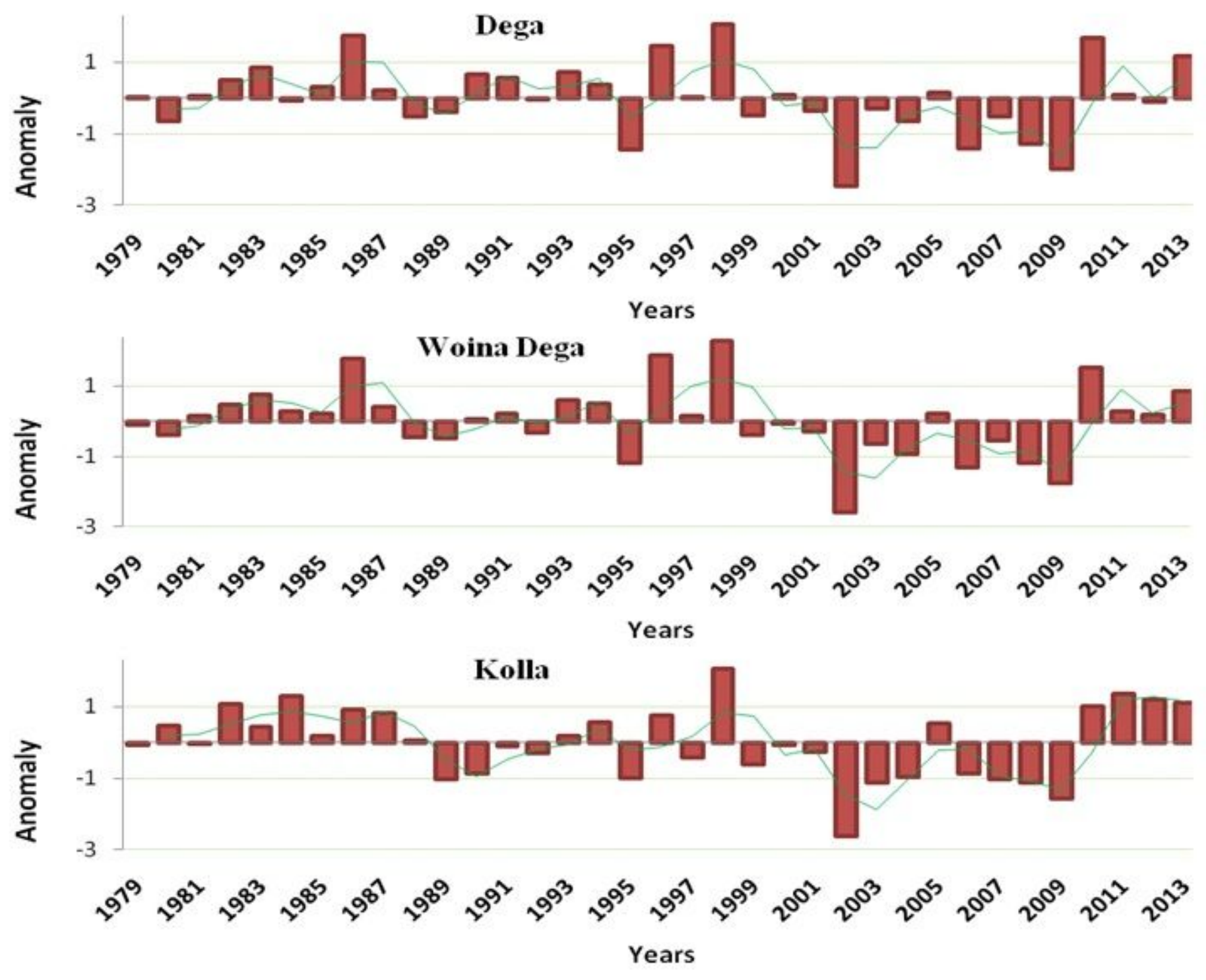

Figure 7

Mean Annual Rainfall Anomalies by AEZs (1979-2013) 